\title{
Mud-Based Construction Material: Promising Properties of French Gravel Wash Mud Mixed with Byproducts, Seashells and Fly Ash as a Binder
}

\author{
Yassine El Mendili ${ }^{1, *} \mathbb{0}$, Manal Bouasria ${ }^{1}$, Mohammed-Hichem Benzaama ${ }^{1}$, Fouzia Khadraoui ${ }^{1}$, Malo Le Guern ${ }^{1}$,

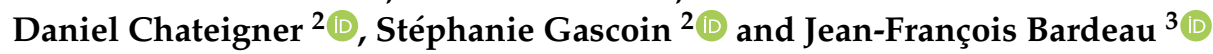 \\ 1 Laboratoire ESITC, COMUE Normandie Université, 1 Rue Pierre et Marie Curie, 14610 Epron, France; \\ manal.bouasria@esitc-caen.fr (M.B.); mohammed-hichem.benzaama@esitc-caen.fr (M.-H.B.); \\ fouzia.khadraoui-mehir@esitc-caen.fr (F.K.); malo.leguern@esitc-caen.fr (M.L.G.) \\ 2 CRISMAT-ENSICAEN, UMR CNRS 6508, ENSICAEN, Université de Caen Normandie, 6 Boulevard Maréchal \\ Juin, 14050 Caen, France; daniel.chateigner@ensicaen.fr (D.C.); stephanie.gascoin@ensicaen.fr (S.G.) \\ 3 Institut des Molécules et Matériaux du Mans (IMMM), UMR CNRS 6283, Le Mans Université, Avenue Olivier \\ Messiaen, 72085 Le Mans, France; Jean-Francois.Bardeau@univ-lemans.fr \\ * Correspondence: yassine.el-mendili@esitc-caen.fr; Tel.: +33-231-452-628
}

\section{check for} updates

Citation: El Mendili, Y.; Bouasria, M.; Benzaama, M.-H.; Khadraoui, F.;

Le Guern, M.; Chateigner, D.;

Gascoin, S.; Bardeau, J.-F. Mud-Based

Construction Material: Promising

Properties of French Gravel Wash

Mud Mixed with Byproducts,

Seashells and Fly Ash as a Binder.

Materials 2021, 14, 6216. https://

doi.org/10.3390/ma14206216

Academic Editor: Alex Kondratiev

Received: 1 October 2021

Accepted: 14 October 2021

Published: 19 October 2021

Publisher's Note: MDPI stays neutral with regard to jurisdictional claims in published maps and institutional affiliations.

Copyright: (C) 2021 by the authors. Licensee MDPI, Basel, Switzerland. This article is an open access article distributed under the terms and conditions of the Creative Commons Attribution (CC BY) license (https:/ / creativecommons.org/licenses/by/ $4.0 /)$.

\begin{abstract}
The French gravel industry produces approximatively 6.5 million tons of gravel wash mud each year. This material offers very promising properties which require an in-depth characterization study before its use as a construction material, otherwise it is removed from value cycles by disposal in landfills. We examined the suitability of gravel wash mud and seashells, with fly ash as a binder, as an unfired earth construction material. Thermal and mechanical characterizations of the smart mixture composed of gravel wash mud, Crepidula fornicata shells and fly ash are performed. The new specimens exhibit high compressive strengths compared to usual earth construction materials, which appears as a good opportunity for a reduction in the thickness of walls. The use of fly ash and Crepidula shells in addition to gravel wash mud provides high silica and calcium contents, which both react with clay, leading to the formation of tobermorite and Al-tobermorite as a result of a pozzolanic reaction. Considering the reduction in porosity and improvements in strength, these new materials are good candidates to contribute significantly to the Sustainable Development Goals (SDGs) and reduce carbon emissions.
\end{abstract}

Keywords: earth construction; gravel wash mud; byproducts; thermal properties; mechanical performance

\section{Introduction}

Earth is one of the most ancient and extensively used building materials worldwide [1]. Historically, raw earth has been one of the main building materials in ancient cities such as Harappa (Pakistan), Duheros (España), Akhlet-Aton (Egypt), Jericho (Palestine), ChanChan (Peru), Atal-Huyuk (Turkey), Babylon (Iraq), Marrakech (Morocco) and others [1-4]. During the past centuries, overshadowed by the architecture of the fossil fuel consumption era, earth-based building materials are nowadays slowly regaining their status and becoming an integral part of sustainable construction [5]. In addition, earth has excellent abilities to maintain a more stable and higher indoor humidity level and thermal mass potential than the most commonly used building materials [6]. Earthen building construction is perhaps the most cost-effective solution to housing problems, with a limited demand on resources.

Mud is a mixture of fine-grained earth material and water. It offers significant sustainability as a building material [7-10]. One of the basic principles of sustainable construction practice is to use locally available materials, a characteristic of mud worldwide. Almost 
any type of mud can be used for construction once all the properties are tested and validated and the required ingredients added. Recently investigated mud materials include gravel wash muds (GWM) [11,12] and waste mud from gravel quarries. These refer to wet deposits that are generated during the extraction of gravel and the gravel aggregates in addition to sand washing. In France, the demand for aggregates reached 435 million tons in 2019 according to UNICEM, the national quarry industry and construction materials association [13], with $27 \%$ of this volume being concrete. Aggregates are used for the realization of civil engineering works, roads and buildings. The French gravel industry produces approximatively 6.5 million tons of gravel wash mud per year, according to UNICEM [13]. Due to its characteristics, this material could be used as a secondary raw material for various applications $[11,12,14]$. However, it is generally removed from recycling by disposal in landfills.

Zami and Lee [15] have shown that building with mud has many advantages, such as lower cost due to efficiency improvements and reduced energy and raw material consumption. In addition, by using locally available low-energy materials, the local economy is helped by increasing the labor cost and by generating new value. Mud is a mixture of multiple clay minerals whose structure is of upmost importance since they directly affect the durability and strength of the mud. The clay minerals are natural composites composed of layered hydrated alumino-silicates classed into four main groups, i.e., kaolin, illite, smectite and chlorite [16]. The smectite group is characterized by an extremely expandable crystal structure (upon hydration and heavy-element uptake), while illite, kaolin, chlorite and sepiolite are non-expandable clays. Expandable clays are subject to large volume variations (swelling and shrinking) upon contact with water [17]. Due to this, after water evaporation, drastic shrinkage and cracking can occur.

The use of byproducts with raw earth or GWM components can be considered a technically feasible green-like operation. Indeed, it does not require final combustion of the components, and this avoids the corresponding GHG emissions. Besides, it can solve the problem of shrinkage and cracking of clay minerals [18]. Consequently, by substituting traditional materials with such wastes, the building industry can achieve significant environmental benefits compared to the current situation [19].

The current research focuses on adapting earthen architecture to local and modern environments by using waste as an additive to earth for construction. For example, in Colombia, Villamizar et al. studied the effects of the addition of cassava peels and coal ash on the mechanical properties of compressed earth blocks [20]. They showed that coal ash led to the stabilization of the compressed blocks and that the cassava peels considerably improved the dry strength of the compressed blocks. In Brazil, Lima et al. were inspired to use sugarcane bagasse ash, resulting from industrial processes, as an additive to compressed earth blocks [21]. Their compressive strength and absorption test studies showed that such additives do not deteriorate the mechanical properties.

Thomas et al. proved that clay soil and oyster shell powder ground with rice husk ash were suitable as a binder for unfired mud bricks [22]. The conventional unfired bricks exhibit a larger compressive strength for $10 \%$ replacement of clayey soil by shell. The calcium carbonate from the oyster shells reacts with alumino-silicates and silicate-rich pozzolanic materials, leading to the formation of hydraulic products such as calcium silicate hydrates (CSHs) and calcium aluminate silicate hydrates (CASHs) [23-25]. The durability and the stability of these CSHs and CASHs depend on the structure of alumina and calcium siliceous phases, which influence their pozzolanicity and thus their mechanical performance.

Clayey earth soils undergo differential settlements, poor shear strength and high compressibility, and must be stabilized to enhance their mechanical performance. Chemical stabilization is a recently proposed technique to achieve this [26]. Fly ash (FA) stabilization is gaining more importance recently [27-29]. Indeed, FA has been extensively used as a binder and is a residue originating from coal-fired power plants. France generates around 3 million of FA annually [30]. The properties of FA, such as low permeability, 
low specific gravity and a high internal friction angle, lead to an increase in the earth bearing capacity and reduces its compressibility and settlement $[27,29]$. In addition, fly ash provides additional alumino-silicates brought into the system and thus amplifies the reactive surface for pozzolanic reaction $[27,28]$. These additional alumino-silicates can also react with calcium hydroxide originating from the hydration of Crepidula shells or clays $[27,28,31]$.

Mud can be used either directly to construct walls or in the form of compressed mud blocks. The most popular mud or earth building techniques are rammed earth, daub, compressed earth blocks and cob [32]. In our region (Normandy, France), the most popular earth building technique is cob (Bauge in French), which uses a mixture of earth and fibers, such as straw [33].

In this paper, we study the suitability of gravel wash mud (GWM) and Crepidula fornicata shell powder, using fly ash as a binder, as a traditional cob material. The compressive strength and expanding properties of cob specimens based on GWM, CR and FA are investigated. Thermal properties and analysis of the formed hydrated products are also examined.

\section{Materials and Techniques}

\subsection{Materials}

\subsubsection{Gravel Wash Mud}

The GWM was collected from a decantation basin of a gravel and sand company, operated by LafargeHolcim granulat (located at Yville-sur-Seine and Anneville-Ambourville in Normandy, France). The Lafarge gravel industry produces approximatively 200 tons of gravel wash mud at the Sablons quarry per year. The GWM water content is about $75 \%$ by weight. The GWM samples were dried for $6 \mathrm{~h}$ in an oven $\left(\right.$ at $\left.105^{\circ} \mathrm{C}\right)$ and then crushed into a fine powder. The use of GWM requires an in-depth characterization study before it is upgraded as a construction material.

\subsubsection{Fibers}

It is known that fibers are added in earth construction as reinforcement and insulating materials. In this study, we use widely available and cheap wheat straws, which represent a low environmental impact. Additionally, only residual straws are used in order to prevent ILUC effects and keep their valorization with the largest renewability and $\mathrm{CO}_{2}$ emission neutrality as possible. The thermal conductivity of cheap wheat straw fibers is between 0.035 and $0.054 \mathrm{~W} \cdot \mathrm{m}^{-1} \cdot \mathrm{K}^{-1}$ [33].

The wheat straws are provided by the local farmers (Laulne, Normandy). The physical properties of straw fibers are presented in Table 1.

Table 1. Properties of Our Wheat Straw Fibers.

\begin{tabular}{ccccc}
\hline $\begin{array}{c}\text { Diameter } \\
(\mathbf{m m})\end{array}$ & $\begin{array}{c}\text { Length } \\
(\mathbf{c m})\end{array}$ & $\begin{array}{c}\text { Density } \\
\left(\mathbf{K g} \cdot \mathbf{m}^{-3}\right)\end{array}$ & $\begin{array}{c}\text { Initial Water Content } \\
\mathbf{( \% )}\end{array}$ & $\begin{array}{c}\text { Tensile Strength } \\
\mathbf{( M P a})\end{array}$ \\
\hline $1-4$ & $10-58$ & $1910 \pm 5$ & 10.7 & $23.9 \pm 3.5$ \\
\hline
\end{tabular}

\subsubsection{Fly Ash}

We used a class $\mathrm{F}$ fly ash (FA) originating from coal-fired power plants, certified to an EN 450-1 standard with an absolute density of $2840 \mathrm{~kg} / \mathrm{m}^{3}$ and a Blaine finesse of $3950 \mathrm{~cm}^{2} / \mathrm{g}$. The FA byproducts were provided by the SURSCHISTE suppliers based in the north of France (Hornaing), producing approximatively 120,000 tons of FA per year. The used FA is a powder with spherical grains, which does not require further processing. Its chemical composition is given in Table 2. 
Table 2. Chemical Composition of Fly Ash in Weight.\% Obtained by Energy-Dispersive X-ray Spectroscopy.

\begin{tabular}{cccccccccccccc}
\hline Component & $\mathrm{SiO}_{2}$ & $\mathrm{CaO}$ & $\mathrm{Fe}_{2} \mathrm{O}_{3}$ & $\mathrm{Al}_{2} \mathbf{O}_{3}$ & $\mathrm{~K}_{2} \mathbf{O}$ & $\mathbf{M g O}$ & $\mathrm{TiO}_{2}$ & $\mathrm{SO}_{3}$ & $\mathrm{Na}_{2} \mathrm{O}_{2}$ & $\mathbf{M n O}_{2}$ & $\mathbf{P}_{2} \mathrm{O}_{5}$ & $\mathrm{Cl}$ \\
\hline wt. $\%$ & 53.3 & 5.1 & 8.5 & 23.6 & 3.0 & 3.0 & 1.0 & 1.1 & 0.6 & 0.5 & 0.2 & 0.1 \\
\hline
\end{tabular}

The XRD pattern of FA can reasonably refined (Figure 1) using 7 different phases (Table 3). The agreement factors $R_{w p}=6.8 \%, R_{B}=5.9 \%$ and a goodness-of-fit below 2 $(\mathrm{GoF}=1.7)$ both indicate the good reliability of our analyses. The microstrain values are also fitted during this step, and remain low for all the phases.

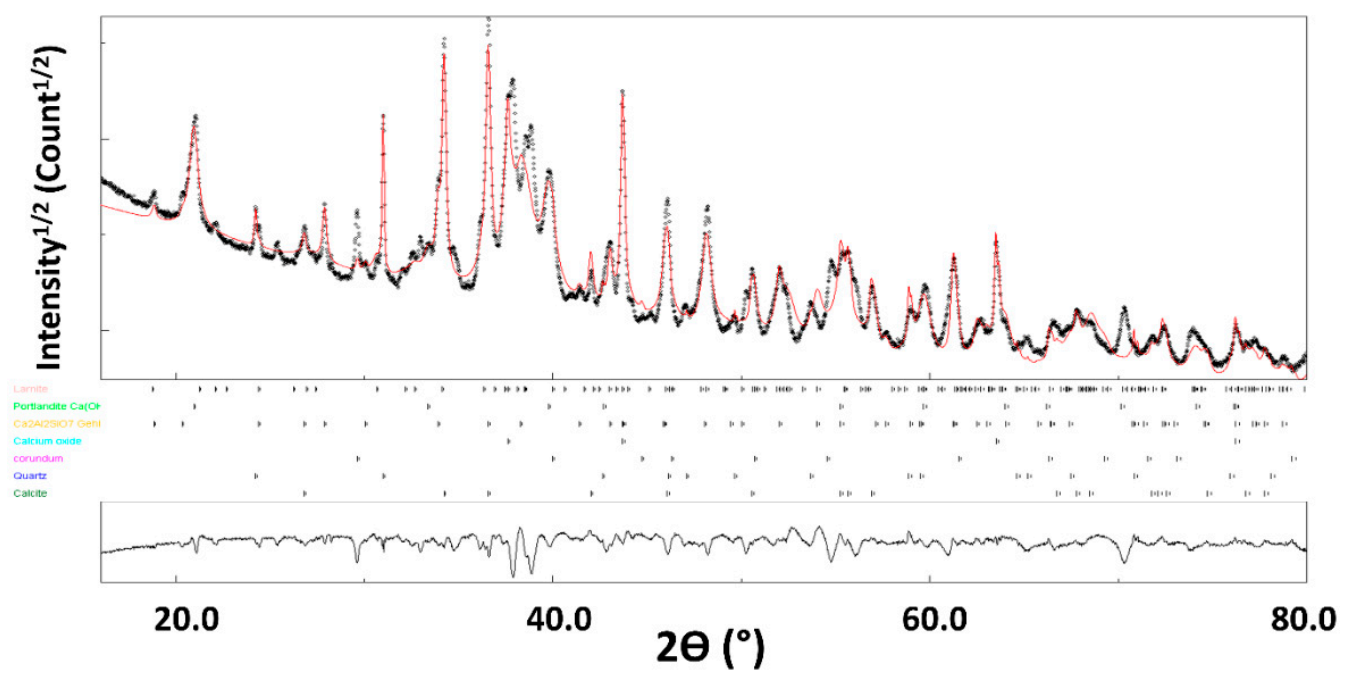

Figure 1. X-ray diffraction diagram of FA. The calculated diagram (red color) is superimposed onto the experimental profile (black color). At the bottom, we present the difference curve $\left(\mathrm{I}_{\exp }-\mathrm{I}_{\text {calc }}\right)$.

Table 3. The Mineralogical Composition of FA.

\begin{tabular}{|c|c|c|c|c|c|c|}
\hline Phases & $\begin{array}{c}\text { COD } \\
\text { Reference }\end{array}$ & V (\%) & $\begin{array}{c}\text { Lattice Type } \\
+ \text { Space Group }\end{array}$ & $\begin{array}{l}\text { Lattice Parameters } \\
\text { (§) }\end{array}$ & $\begin{array}{c}\langle\mathrm{D}\rangle \\
(\mathrm{nm})\end{array}$ & $\left\langle\varepsilon^{2}\right\rangle^{1 / 2}$ \\
\hline $\begin{array}{l}\text { Calcite } \\
\mathrm{CaCO}_{3}\end{array}$ & 1547347 & $10.5(3)$ & $\begin{array}{l}\text { Trigonal } \\
\text { R-3c:H }\end{array}$ & $\begin{array}{c}a=4991 \\
c=17,101\end{array}$ & 77 (5) & $1 \times 10^{-4}$ \\
\hline $\begin{array}{l}\text { Quartz } \\
\mathrm{SiO}_{2}\end{array}$ & 1526860 & $2.7(2)$ & $\begin{array}{c}\text { Trigonal } \\
\mathrm{P}_{2} 21\end{array}$ & $\begin{array}{l}a=4919 \\
c=5408\end{array}$ & $362(20)$ & $1 \times 10^{-4}$ \\
\hline $\begin{array}{c}\text { Corundum } \\
\mathrm{Al}_{2} \mathrm{O}_{3}\end{array}$ & 1000017 & $1.1(2)$ & $\begin{array}{l}\text { Trigonal } \\
\text { R-3c:H }\end{array}$ & $\begin{array}{c}a=4704 \\
c=13,653\end{array}$ & $135(5)$ & $1 \times 10^{-4}$ \\
\hline $\begin{array}{c}\text { Calcium } \\
\text { oxide } \\
\mathrm{CaO}\end{array}$ & 1000044 & $2.9(2)$ & $\begin{array}{l}\text { Cubic } \\
\text { Fm-3m }\end{array}$ & $a=4807$ & $138(5)$ & $1 \times 10^{-4}$ \\
\hline $\begin{array}{c}\text { Gehlenite } \\
\mathrm{Ca}_{2} \mathrm{Al}_{2} \mathrm{SiO}_{7}\end{array}$ & 1000048 & $14.7(4)$ & $\begin{array}{l}\text { Tetragonal } \\
\text { P-421m }\end{array}$ & $\begin{array}{l}a=7714 \\
c=5062\end{array}$ & $66(2)$ & $2 \times 10^{-4}$ \\
\hline $\begin{array}{c}\text { Portlandite } \\
\mathrm{Ca}(\mathrm{OH})_{2}\end{array}$ & 1001768 & $16.9(3)$ & $\begin{array}{l}\text { Trigonal } \\
\text { R-3c:H }\end{array}$ & $\begin{array}{l}a=3595 \\
c=4914\end{array}$ & $55(2)$ & $6 \times 10^{-4}$ \\
\hline $\begin{array}{l}\text { Larnite } \\
\mathrm{Ca}_{2} \mathrm{SiO}_{4}\end{array}$ & 9012789 & $51.2(2)$ & $\begin{array}{l}\text { Monoclinic } \\
\text { P121/n1 }\end{array}$ & $\begin{array}{c}a=5436 \\
b=6769 \\
c=9356 \\
\beta=94,172\end{array}$ & $97(2)$ & $6 \times 10^{-4}$ \\
\hline
\end{tabular}

Quantitative phase analysis using Rietveld refinement indicates that the XRD pattern is indexed by the following major phases: larnite $(51.2 \%)$, portlandite $(16.9 \%)$, gehlenite $(14.7 \%)$ and calcite $(10.5 \%)$, with minor occurrence of quartz, calcium oxide and corundum. 


\subsubsection{Crepidula Fornicata Shells}

Crepidula fornicate $(\mathrm{CR})$ are an invasive gastropod species causing problems in regard to halieutic resources due to its overgrowth on the coasts. For this work, the ground CR shells were provided by a fishing factory in Normandy. The crude shells were dried for $24 \mathrm{~h}$ in an oven at $105^{\circ} \mathrm{C}$ and ground to powders in the ESITC laboratory through a 63-micron sieve. The specific gravity and the Blaine fineness were $2730 \mathrm{~kg} \cdot \mathrm{m}^{-3}$ and $8140 \mathrm{~cm}^{2} \cdot \mathrm{g}^{-1}$. The elemental composition of CR powders was achieved by energy-dispersive $\mathrm{X}$-ray spectroscopy (EDX) [34]. Calcium is the major cation. EDS also shows the presence of traces of $\mathrm{Na}, \mathrm{Si}, \mathrm{Na}, \mathrm{Mg}$, $\mathrm{Al}$ and $\mathrm{S}$. In addition, X-ray diffraction and Raman analysis show aragonite as the main phase of Crepidula $[34,35]$.

\subsubsection{Mix Design}

Different mixes with various compositions were studied before reaching the optimal mixture (presented in this work), which exhibits the best mechanical and thermal performances.

The straw cuts, $5 \mathrm{~cm}$ long, were added randomly and mixed with the other components until the composite became homogeneous. The straw and the water contents were $2 \%$ and $18 \%$ by weight, respectively [36].

The optimized mix (Table 4) material (GWM-FA-CR) was placed into prismatic molds $(30 \mathrm{~cm} \times 30 \mathrm{~cm} \times 4 \mathrm{~cm})$ for thermal tests and into cylindrical molds $(11 \mathrm{~cm}$ diameter and $22 \mathrm{~cm}$ height) for compressive tests (Figure 2).

Table 4. Composition of the GMW-FA-CR Mix.

\begin{tabular}{cccccc}
\hline Mix & GWM & FA & CR & Fiber & Water \\
\hline Mass $(\%)$ & 50 & 25 & 5 & 2 & 18 \\
\hline
\end{tabular}
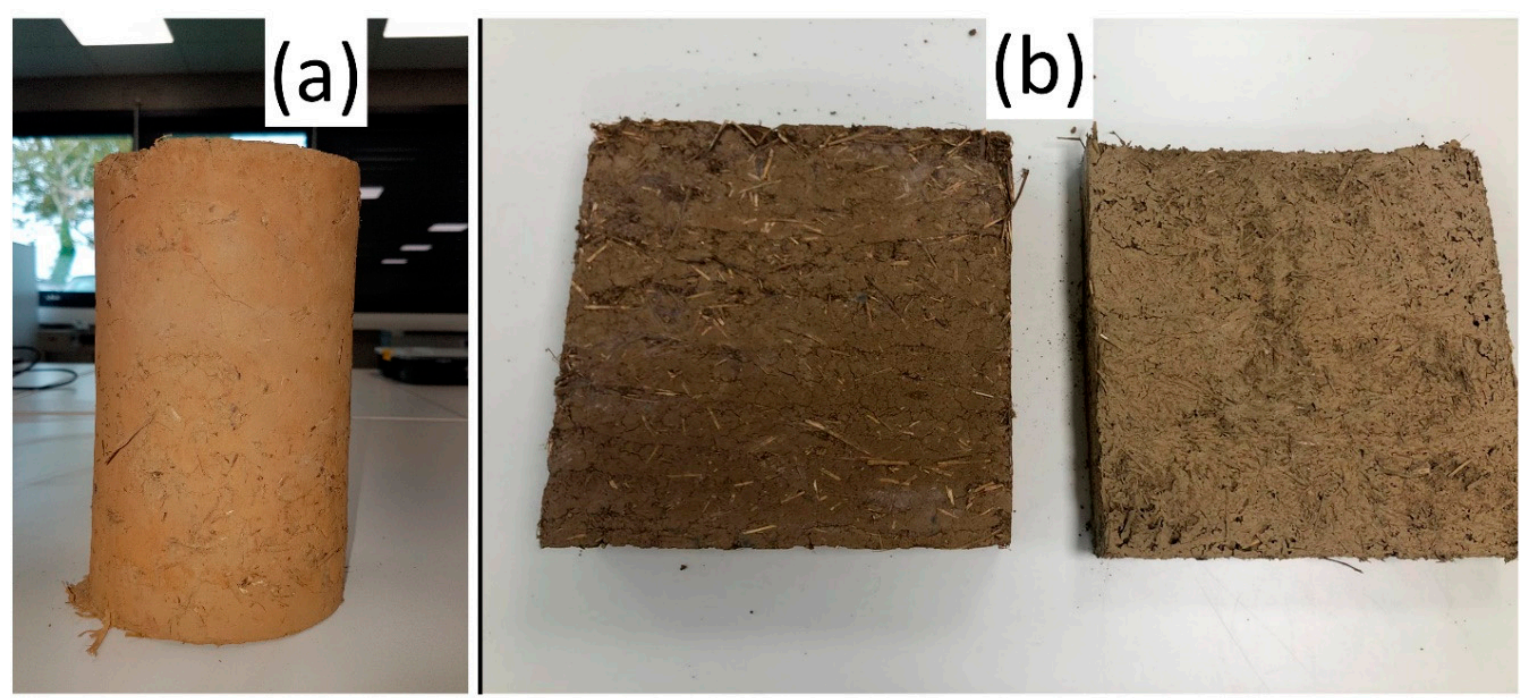

Figure 2. (a) Sample used for mechanical tests $(\varnothing 11 \mathrm{~cm} \times 22 \mathrm{~cm})$ and (b) samples used for thermal analysis $(30 \mathrm{~cm} \times 30 \mathrm{~cm} \times 4 \mathrm{~cm})$.

After the GWM, FA and CR are mixed by hand and dry, water is added until the mixture becomes fluid. The cheap wheat straws are added gradually for $120 \mathrm{~s}$. The GWMFA-CR is then compacted manually and stored for $24 \mathrm{~h}$ at $20 \pm 1{ }^{\circ} \mathrm{C}$. After this period, the mix is then compacted manually in molds. The prepared molds are stored at room temperature for $48 \mathrm{~h}$ and then transferred for $48 \mathrm{~h}$ in an oven at $40^{\circ} \mathrm{C}$. The duration of drying is 3 weeks. After the drying process period, the mixture is kept under ambient conditions $\left(20{ }^{\circ} \mathrm{C}\right.$ and $50 \%$ relative humidity). 
The samples are ready for characterization once equilibrium is reached (the mass difference is less than $0.1 \%$ between 2 daily weightings). Generally, the equilibrium is obtained after $48 \mathrm{~h}$ at room temperature $\left(20 \pm 1^{\circ} \mathrm{C}\right)$.

The first observations show that no cracking is observed and that the shrinkage remains very low $(<1 \%)$ for GWM-FA-CR after 3 weeks. The specific gravity of the specimen is around $1910 \mathrm{~kg} \cdot \mathrm{m}^{-3}$.

\subsection{Experimental Techniques}

Chemical analyses were performed by energy-dispersive $\mathrm{X}$-ray spectroscopy (EDS) using a SUPRA ${ }^{\mathrm{TM}} 55$ (SAPPHIRE; Carl Zeiss, Jena, Germany).

The Raman analyses were conducted using a DXR Thermo Scientific microscope (Wattam, MA, USA), employing a $532 \mathrm{~nm}$ laser source with a $2 \mathrm{~mW}$ laser with an integration time of $120 \mathrm{~s}$ and a nominal spectral resolution of $3 \mathrm{~cm}^{-1}$. The Origin software was used to fit the spectra. The mineralogical composition was achieved using the Raman Open Database [37].

$X$-ray diffraction analyses were recorded using a D8 Advance Vario 1 Bruker instrument equipped with pure-copper $\mathrm{K} \alpha$ radiation $(\lambda=1.54059 \AA)$. X-ray data presented in this study are collected from $15^{\circ}$ to $80^{\circ}$ for $1 \mathrm{~s}$ per $0.01^{\circ}$ step (with $2 \theta$ varying and $16 \mathrm{~h}$ per scan). The instrumental calibration is obtained by analyzing the $\mathrm{LaB}_{6}$ standard powder [38]. Quantification and crystalline phase identification were performed using the FPSM procedure (full-pattern search-match) and the COD database [39]. The diffraction patterns for the studied samples exhibit several phases. For the assignment of all the phases present in the XRD diagram, the elemental and chemical composition are primordial. For this purpose, the XRF and EDS analyses on the analyzed specimen were performed before. A rapid phase analysis using the online FPSM procedure: http:/ / nanoair.dii.unitn.it:8080/sfpm/fpsmTest.html (accessed on 10 September 2021) was conducted to determine the probable phases as well as the lattice parameters for each phase. The COD database then provided the necessary information of crystal structures and the average size of each structure. The basis of the FPSM quantifications is the automatic identification of the first list of crystals. The complete list of phases is obtained using micro-Raman spectroscopy due to its larger sensitivity. Finally, a Rietveld quantification was performed using the MAUD software using the appropriate phases [40].

The thermogravimetric measurements were carried out using the NETZSCH instrument (STA 449 F5 Jupiter) on $60-80 \mathrm{mg}$ of powders placed in an alumina pan with a heating rate of $10{ }^{\circ} \mathrm{C} / \mathrm{min}$ from $20^{\circ} \mathrm{C}$ to $900{ }^{\circ} \mathrm{C}$ in a Ar-flowing environment $(50 \mathrm{~mL} / \mathrm{min})$.

Measurements of water vapor permeability were based on the wet cup method according to the standard NF EN ISO 12572 [41].

The dynamic vapor sorption (DVS) technique is used to investigate the solids' interaction with vapor. In present study, sorption isotherms of the mixtures are studied according to the standard ISO 12571.

The thermal conductivity was conducted using a HFM (NETZSCH, Model HFM 436 Lambda) [26].

The specific heat capacity of a mixture is conducted according to the standard ISO 11357-4 [42] and using differential scanning calorimetry (NETZSCH, model STA 449 F3).

For the analyzes of specific surface area and the absolute density, we used the BET method [43] and a helium pycnometer (model Accupyc II 1340), respectively.

The mechanical resistance tests of the cylindrical GWM-FA-CR sample after 28 days were carried out by an electromechanical press of the IGM company. The compression tests were conducted by the application of an increasing load at constant speeds of $0.05 \mathrm{kN} / \mathrm{s}$. The compressive strength is measured at $2 \%$ of shrinkage, which is representative of the earth wall behavior [26]. 


\section{Results and Discussion}

\subsection{Physical and Chemical Properties of GWM}

The GWM material contains mainly silicon, iron, calcium and aluminum for the major cations (Table 5), coherently with a clayey mud.

Table 5. Physical and chemical properties of GWM.

\begin{tabular}{cc}
\hline Element & $\%$ \\
\hline $\mathrm{SiO}_{2}$ & 61.3 \\
$\mathrm{Al}_{2} \mathrm{O}_{3}$ & 9.8 \\
$\mathrm{Fe}_{2} \mathrm{O}_{3}$ & 10.2 \\
$\mathrm{CaO}$ & 10.1 \\
$\mathrm{MgO}$ & 2.9 \\
$\mathrm{Na}{ }_{2} \mathrm{O}$ & 0.1 \\
$\mathrm{~K}_{2} \mathrm{O}$ & 1.8 \\
$\mathrm{SO}_{3}$ & $<0.1$ \\
$\mathrm{P}_{2} \mathrm{O}_{5}$ & $<0.1$ \\
$\mathrm{Cl}^{-}$ & 0.11 \\
\hline Physical and Hygrothermal Properties & - \\
\hline Specific surface (in $\mathrm{cm}^{2} \cdot \mathrm{g}^{-1}$ ) & 4120 \\
Absolute density (in $\mathrm{kg} \cdot \mathrm{m}^{-3}$ ) & 925 \\
Thermal conductivity (in W.m ${ }^{-1} \cdot \mathrm{K}^{-1}$ ) & $0.935 \pm 0.01$ \\
Water vapor permeability (in & $2.4 \times 10^{-11}$ \\
kg.m & \\
\hline
\end{tabular}

The particle size distribution of GWM powder (Figure 3), measured using laser diffraction, exhibits $d_{10}$ and $d_{90}$ values of 3.67 and $46.33 \mu \mathrm{m}$, respectively. Particles with sizes less than $63 \mu \mathrm{m}$ are about $98 \%$ of all particles.

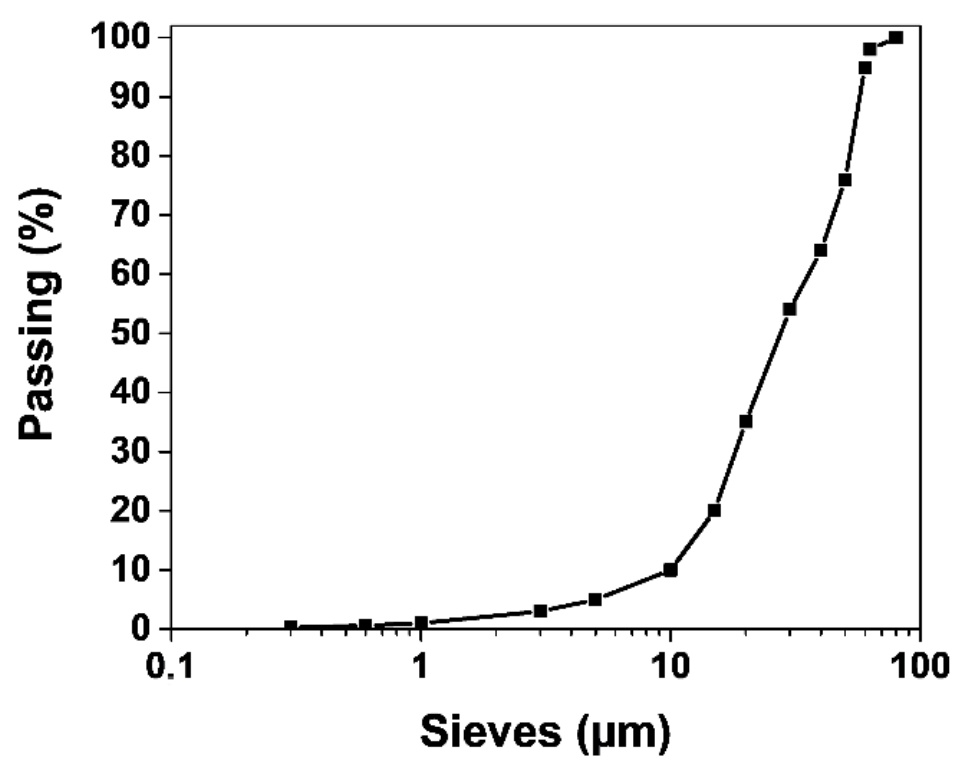

Figure 3. Particle size distribution of GWM powder.

While EDS analysis only provides element characterization, it can be important to know what crystalline phases these elements form in the material. For instance, $\mathrm{Si}$ atoms can be located in quartz and/or clays, two phases with very different behavior when incorporated into cob. The first phase analysis by the online FPSM procedure was launched. The FPSM uses a Rietveld fitting procedure to test all possible crystal structures from the COD database (restricted to the EDS-detected elements) which provides a ranked list of candidates for further quantification. The XRD diagram of the GWM powder is then fitted 
with the previous phase identification by FPSM. The XRD pattern of the GWM is reasonably refined (Figure 4) using eight different phases (Table 6). The agreement factors $R_{w p}=4.7 \%$, $\mathrm{R}_{\mathrm{B}}=3.6 \%$ and a goodness-of-fit below $2(\mathrm{GoF}=1.7)$ both indicate the good reliability of our analyses. The microstrain values are also fitted during this step, and remain low for all the phases.

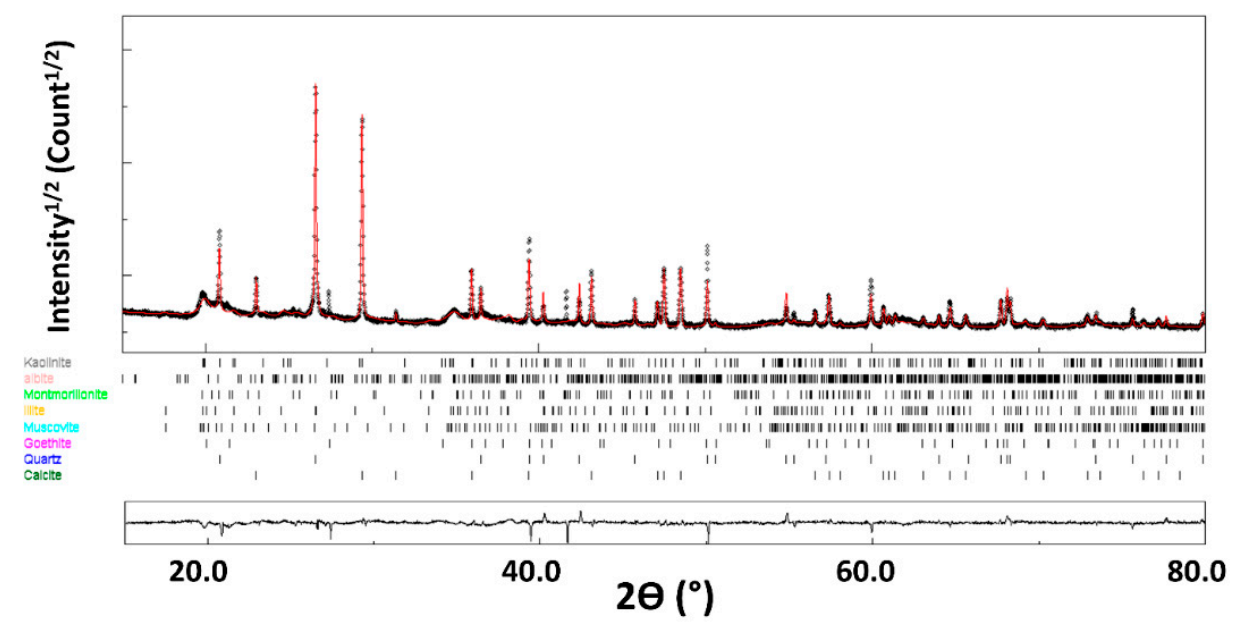

Figure 4. X-ray diffraction diagram of GWM. The calculated diagram (red color) is superimposed onto the experimental profile (black color). At the bottom, we present the difference curve $\left(\mathrm{I}_{\text {exp }}-\mathrm{I}_{\text {calc }}\right)$.

Table 6. The Mineralogical Composition of GWM.

\begin{tabular}{|c|c|c|c|c|c|c|}
\hline Phases & $\begin{array}{c}\text { COD } \\
\text { Reference }\end{array}$ & V (\%) & $\begin{array}{c}\text { Lattice Type } \\
+ \text { Space Group }\end{array}$ & $\begin{array}{l}\text { Lattice Parameters } \\
\text { (§) }\end{array}$ & $\begin{array}{c}\langle\mathrm{D}\rangle \\
(\mathrm{nm})\end{array}$ & $\left\langle\varepsilon^{2}\right\rangle^{1 / 2}$ \\
\hline $\begin{array}{l}\text { Calcite } \\
\mathrm{CaCO}_{3}\end{array}$ & 1547347 & $30.8(3)$ & $\begin{array}{l}\text { Trigonal } \\
\text { R-3c:H }\end{array}$ & $\begin{array}{c}a=4987 \\
c=17,056\end{array}$ & $392(20)$ & $8 \times 10^{-4}$ \\
\hline $\begin{array}{l}\text { Quartz } \\
\mathrm{SiO}_{2}\end{array}$ & 1526860 & $14.3(2)$ & $\begin{array}{c}\text { Trigonal } \\
\mathrm{P}_{2} 21\end{array}$ & $\begin{array}{l}a=4915 \\
c=5407\end{array}$ & 219 (10) & $4 \times 10^{-4}$ \\
\hline $\begin{array}{c}\text { Albite } \\
\mathrm{NaAlSiO}_{3} \mathrm{O}_{8}\end{array}$ & 1556999 & $2.3(2)$ & $\begin{array}{l}\text { Triclinic } \\
\text { P1 }\end{array}$ & $\begin{array}{c}a=8166 \\
b=12845 \\
c=7188 \\
\alpha=94,240 \\
\beta=116,590 \\
\gamma=87,715\end{array}$ & $30(5)$ & $6 \times 10^{-3}$ \\
\hline $\begin{array}{c}\text { Kaolinite } \\
\mathrm{Al}_{2} \mathrm{Si}_{2} \mathrm{O}_{5}(\mathrm{OH})_{4}\end{array}$ & 1011045 & $12.8(2)$ & $\begin{array}{l}\text { Monoclinic } \\
\text { Cc:b1 }\end{array}$ & $\begin{array}{c}a=5246 \\
b=8886 \\
c=14,672 \\
\beta=100,565\end{array}$ & $26(5)$ & $6 \times 10^{-4}$ \\
\hline $\begin{array}{c}\text { Illite } \\
\left(\mathrm{K}, \mathrm{H}_{3} \mathrm{O}\right)(\mathrm{Al}, \mathrm{Mg}, \mathrm{Fe})_{2}(\mathrm{Si}, \mathrm{Al})_{4} \\
\mathrm{O}_{10}\left[(\mathrm{OH})_{2},\left(\mathrm{H}_{2} \mathrm{O}\right)\right]\end{array}$ & 2300190 & $16.1(4)$ & $\begin{array}{l}\text { Monoclinic } \\
\mathrm{C} 2 / \mathrm{m}: \mathrm{b} 1\end{array}$ & $\begin{array}{c}a=5171 \\
b=8942 \\
c=10,229 \\
\beta=100,683(1)\end{array}$ & $70(5)$ & $2 \times 10^{-4}$ \\
\hline $\begin{array}{c}\text { Goethite } \\
\alpha-\mathrm{FeO}(\mathrm{OH})\end{array}$ & 2211652 & $2.4(3)$ & $\begin{array}{l}\text { Orthorhombic } \\
\text { Pbnm:cab }\end{array}$ & $\begin{array}{l}a=4579 \\
b=9945 \\
c=2998\end{array}$ & $21(1)$ & $6 \times 10^{-4}$ \\
\hline $\begin{array}{c}\text { Montmorillonite } \\
(\mathrm{Na}, \mathrm{Ca})_{0.3} \\
(\mathrm{Al}, \mathrm{Mg})_{2} \mathrm{Si}_{4} \mathrm{O}_{10}(\mathrm{OH})_{2}\end{array}$ & 1100106 & $14.8(2)$ & $\begin{array}{l}\text { Monoclinic } \\
\text { C2/c:b1 }\end{array}$ & $\begin{array}{c}a=5451 \\
b=9067 \\
c=10,255 \\
\beta=100,780\end{array}$ & $125(4)$ & $6 \times 10^{-4}$ \\
\hline $\begin{array}{c}\text { Muscovite } \\
\mathrm{KAl}_{2}\left(\mathrm{AlSi}_{3} \mathrm{O}_{10}\right)(\mathrm{F}, \mathrm{OH})_{2}\end{array}$ & 1100011 & $6.7(4)$ & $\begin{array}{l}\text { Monoclinic } \\
\text { C2/c:b1 }\end{array}$ & $\begin{array}{l}a=5183 \\
b=9006 \\
c=20,186 \\
\beta=95,702\end{array}$ & $89(5)$ & $2 \times 10^{-3}$ \\
\hline
\end{tabular}


Quantitative phase analysis using Rietveld refinement indicates that the XRD diagrams are indexed by the following major phases: calcite $(30.8 \%)$, quartz $(14.3 \%)$, montmorillonite $(14.8 \%)$, illite $(16.1 \%)$ and kaolinite $(12.8 \%)$, with minor occurrence of albite, goethite and muscovite.

Muscovite is a hydrated phyllosilicate mineral containing aluminum and potassium [44]. Albite is a mineral of the feldspars family (silicate group, tectosilicate subgroup) with the formula $\mathrm{NaAlSi}_{3} \mathrm{O}_{8}$, which may contain traces of $\mathrm{Ca}, \mathrm{K}$ and $\mathrm{Mg}$ [45]. Goethite is a mineral species, a variety of iron (III) oxyhydroxide and an $\alpha$ polymorph of the compound $\mathrm{FeO}(\mathrm{OH})[44]$. Kaolinite is a mineral species composed of hydrated aluminum silicate and belongs to the subgroup of phyllosilicates [44].

Illite is the name of a group of non-swelling clay minerals. Illites are composed of three layers of phyllosilicates-one layer of aluminum (Al) surrounded by two layers of silicate (Si). They are structurally very close to micas (muscovite, biotite) and other silicates (feldspar, feldspathoids, orthosis and others), from which they are produced by bisiallitization, a reaction that takes place when water is attacked under certain temperature and pressure conditions [44]. Montmorillonite is a mineral composed of aluminum silicate and hydrated magnesium. Montmorillonite is a 2:1-type clay, also called TOT (tetrahedron/octahedron/tetrahedron). This means that a montmorillonite sheet is formed of three layers: an octahedral layer of $\mathrm{Al}\left(\mathrm{OH}^{-}\right)_{5} \mathrm{O}$ and two $\mathrm{SiO}_{4}$ tetrahedral layers [44]. One of the most remarkable properties of montmorillonites is their swelling capacity, resulting from the entry of water into the space between the layers. Montmorillonite dispersed in water very easily gives a stable, colloidal suspension. On the other hand, this aptitude for swelling and conversely for shrinkage (collapse of the clay layers during desiccation) poses significant problems from a geotechnical point of view, causing sometimes-significant displacements at the foundations according to variations in humidity of the sub-soil.

Some clays have the ability to increase their interfoliar spaces. This property comes from the incorporation of hydrated cations $(\mathrm{Na}, \mathrm{Ca}$, etc.) making it possible to compensate for permanent charge deficits. This phenomenon no longer exists if the clay charge is too high (e.g., micas or muskovite in our sample: total clay charge of -1 perfectly counterbalanced by the dehydrated cations $(\mathrm{K})$ ) or zero (e.g., pyrophyllite, talc: total clay charge of 0 , no interfoliar cation). The expandable species are those whose charge varies from 0.3 to 0.8 , which includes the subclass of smectites. It is the water incorporated via the hydrated cations which allows the swelling of the crystalline structure. The swelling is all the more important as the humidity is high. The only expandable species present in our GWM is montmorillonite, with a rate of $14.8 \%$. The presence of muscovite, illite, albite and kaolinite in the GWM specimen will influence the shrinkage behavior. These crystals contain small quantities of water and they have a low intercrystalline swelling behavior [46].

\subsection{Characterization of GWM-FA-CR}

\subsubsection{Compressive Strength of GWM-FA-CR}

The results also show that GWM-FA-CR produced larger strengths after 3 weeks of curing compared to those of standard cob materials (Table 7). GWMs are subject to differential settlement and low shear strength, and require additional stabilization to enhance their properties. The use of FA as a stabilizer is one of the proposed solutions. This waste is gaining more importance recently [27-29]. Indeed, FA has been extensively used as a binder. The properties of FA such as low permeability, low specific gravity and a high internal friction angle lead to an increase in the earth bearing capacity and reduces its compressibility and settlement $[27,29]$. In addition, fly ash provides additional calcium silicates and alumino-silicates brought into the system, and thus amplifies the reactive surface for a pozzolanic reaction $[27,28]$. These additional alumino-silicates can also react with calcium hydroxide originating from hydration of Crepidula shells or clays $[27,28,31]$. The formation of calcium silicate and alumino-silicate hydrate products will be confirmed in the next XRD and Raman section. 
Table 7. Compressive strength of the cob and the GWM-FA-CR specimens after 3 weeks of curing compared to those of standard cob building materials from the literature.

\begin{tabular}{cc}
\hline Sample & Compressive Strength (Mpa) \\
\hline GWM-FA-CR & $5.38 \pm 0.23$ \\
Standard cob & $2.03 \pm 0.02$ \\
Cob materials from the literature [33] & $1.42-1.52$ \\
\hline
\end{tabular}

\subsubsection{Analyses of GWM-FA-CR Sample Using XRD}

An XRD pattern of the GWM-FA-CR sample is refined using seven main phases (Figure 5 and Table 8$)$. The agreement factors are: $R_{w p}=7.8 \%$ and $R_{B}=9.7 \%(G o F=1.55)$.

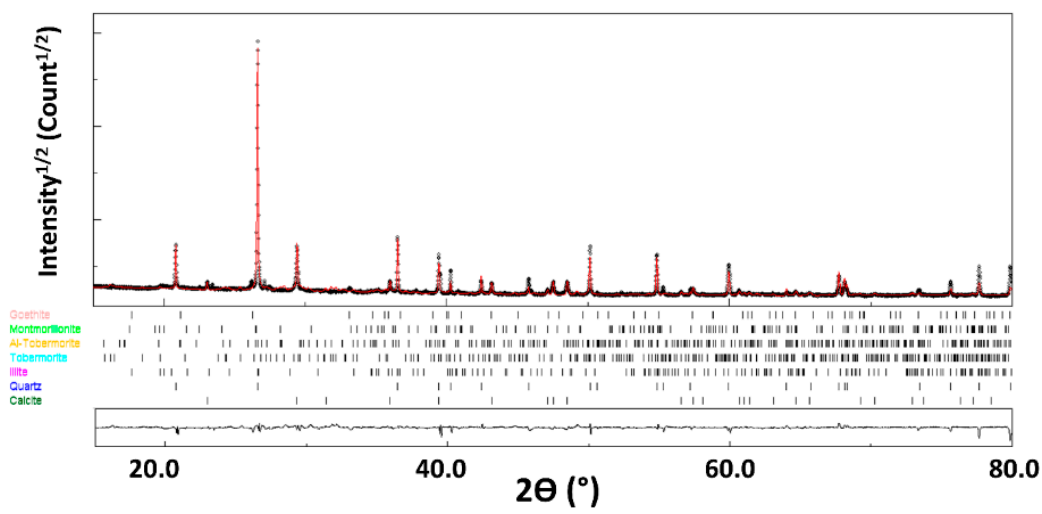

Figure 5. X-ray diffraction diagram of GWM-FA-CR. The calculated diagram (red color) is superimposed onto the experimental profile (black color). At the bottom, we present the difference curve $\left(\mathrm{I}_{\text {exp }}-\mathrm{I}_{\text {calc }}\right)$.

Table 8. The mineralogical composition of GWM-FA-CR after 3 weeks of curing.

\begin{tabular}{|c|c|c|c|c|c|c|}
\hline Phases & $\begin{array}{c}\text { COD } \\
\text { Reference }\end{array}$ & V (\%) & $\begin{array}{c}\text { Lattice Type } \\
+ \text { Space Group }\end{array}$ & $\begin{array}{l}\text { Lattice Parameters } \\
\text { (̊) }\end{array}$ & $\begin{array}{c}\langle\mathrm{D}\rangle \\
(\mathrm{nm})\end{array}$ & $\left\langle\varepsilon^{2}\right\rangle^{1 / 2}$ \\
\hline $\begin{array}{l}\text { Calcite } \\
\mathrm{CaCO}_{3}\end{array}$ & 1547347 & $26.3(5)$ & $\begin{array}{l}\text { Trigonal } \\
\text { R-3c:H }\end{array}$ & $\begin{array}{c}a=4984 \\
c=17,047\end{array}$ & $308(20)$ & $8 \times 10^{-4}$ \\
\hline $\begin{array}{l}\text { Quartz } \\
\mathrm{SiO}_{2}\end{array}$ & 1526860 & $22.3(3)$ & $\begin{array}{c}\text { Trigonal } \\
\mathrm{P}_{2} 21\end{array}$ & $\begin{array}{l}a=4913 \\
c=5404\end{array}$ & $690(10)$ & $5 \times 10^{-4}$ \\
\hline $\begin{array}{c}\text { Montmorillonite } \\
(\mathrm{Na}, \mathrm{Ca})_{0.3} \\
(\mathrm{Al}, \mathrm{Mg})_{2} \mathrm{Si}_{4} \mathrm{O}_{10}(\mathrm{OH})_{2}\end{array}$ & 1100106 & $6.4(2)$ & $\begin{array}{l}\text { Monoclinic } \\
\text { C2/c:b1 }\end{array}$ & $\begin{array}{c}a=5441 \\
b=9003 \\
c=10,250 \\
\beta=100,323\end{array}$ & $66(4)$ & $6 \times 10^{-4}$ \\
\hline $\begin{array}{c}\text { Illite } \\
\left(\mathrm{K}, \mathrm{H}_{3} \mathrm{O}\right)(\mathrm{Al}, \mathrm{Mg}, \mathrm{Fe})_{2}(\mathrm{Si}, \mathrm{Al})_{4} \\
\mathrm{O}_{10}\left[(\mathrm{OH})_{2},\left(\mathrm{H}_{2} \mathrm{O}\right)\right]\end{array}$ & 2300190 & $7.1(3)$ & $\begin{array}{l}\text { Monoclinic } \\
\mathrm{C} 2 / \mathrm{m}: \mathrm{b} 1\end{array}$ & $\begin{array}{l}a=5183 \\
b=8986 \\
c=10,171 \\
\beta=100,50\end{array}$ & $66(5)$ & $1 \times 10^{-4}$ \\
\hline $\begin{array}{c}\text { Tobermorite } \\
\mathrm{Ca}_{5} \mathrm{Si}_{6} \mathrm{O}_{16}(\mathrm{OH})_{2} \cdot 4 \mathrm{H}_{2} \mathrm{O}\end{array}$ & 9005498 & $19.5(3)$ & $\begin{array}{l}\text { Monoclinic } \\
\text { Cm:c2 }\end{array}$ & $\begin{array}{c}a=6806 \\
b=7402 \\
c=22,390 \\
\gamma=124,345\end{array}$ & $58(1)$ & $5 \times 10^{-4}$ \\
\hline $\begin{array}{c}\text { Al-tobermorite } \\
\mathrm{Al}_{0.5} \mathrm{Ca}_{4.9} \mathrm{H}_{10.7} \mathrm{O}_{22} \mathrm{Si}_{5.5}\end{array}$ & 1527001 & $15.6(3)$ & $\begin{array}{l}\text { Monoclinic } \\
\text { Cm:c2 }\end{array}$ & $\begin{array}{c}a=6770 \\
b=7359 \\
c=22,227 \\
\gamma=123,770\end{array}$ & $43(4)$ & $6 \times 10^{-2}$ \\
\hline $\begin{array}{c}\text { Goethite } \\
\alpha-\mathrm{FeO}(\mathrm{OH})\end{array}$ & 2211652 & $2.6(3)$ & $\begin{array}{l}\text { Orthorhombic } \\
\text { Pbnm:cab }\end{array}$ & $\begin{array}{c}a=4588 \\
b=10,093 \\
c=2984\end{array}$ & $19(1)$ & $6 \times 10^{-4}$ \\
\hline
\end{tabular}


Quantitative phase analysis indicates that the XRD lines of the GWM-FA-CR sample are dominated by calcite, quartz, tobermorite and Al-tobermorite. In addition to these phases, montmorillonite, illite and goethite originating from GWM are also detected in lower amounts. Consequently, part of these phases did not react, neither with FA nor with CR. The calcium originating from CR and GWM reacts with alumino-silicates from GWM and silicate-rich FA pozzolanic materials, which leads to the formation of hydrated phases, mainly calcium aluminate silicate (Al-tobermorite) and calcium silicate (Al-tobermorite) hydrates. Tobermorite minerals exhibit orthorhombic symmetry and a basal spacing of $11 \AA$ with the formula $\mathrm{Ca}_{4+\mathrm{x}}\left(\mathrm{Al}_{\mathrm{y}} \mathrm{Si}_{6-\mathrm{y}}\right) \mathrm{O}_{15+2 \mathrm{x}-\mathrm{y}} \cdot 5 \mathrm{H}_{2} \mathrm{O}$, where $\mathrm{x}$ and $\mathrm{y}$ are from 0 to 1 [47]. Tobermorite has a high cation exchange capacity and high selectivity towards $\mathrm{Al}$ [48]. The Al-substituted tobermorite is considered to be a new family of selective cation exchangers [48]. The substitution of Si by Al occurs in the bridging and non-bridging tetrahedron sites $[49,50]$. The synthesized Al-substituted forms of tobermorite are formed in the presence of some raw materials, such as FA $[51,52]$ and/or phases from the CaO$\mathrm{SiO}_{2}-\mathrm{H}_{2} \mathrm{O}$ system [53].

\subsubsection{Analyses of GWM and GWM-FA-CR Sample by DSC}

Figure 6 shows the derivative thermogravimetry calorimetry (DTG) skeletons of the GWM and GWM-FA-CR samples. The mass loss between 100 and $130{ }^{\circ} \mathrm{C}$ is attributed to the dehydration and evaporation of free water. The DTG peak present in the GWM-FA-CR from 85 to $100{ }^{\circ} \mathrm{C}$ is assigned to the evaporation of free water and the dehydration of CSH gel [54]. The other peak located at $130{ }^{\circ} \mathrm{C}$ indicates a dehydration of CASH-type reaction products [55], and the peak above $460^{\circ} \mathrm{C}$ the dehydration of portlandite [56].

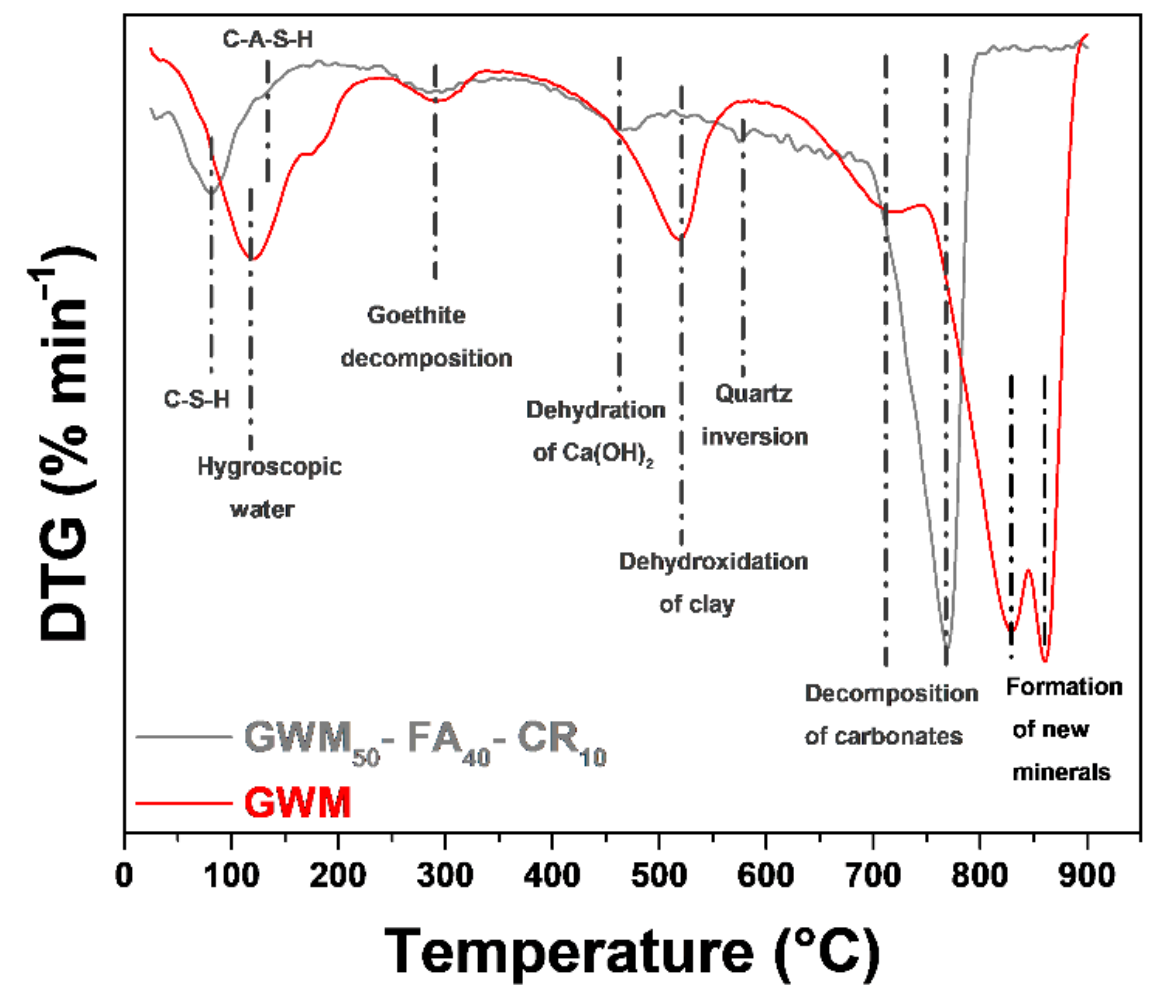

Figure 6. DTG curves of the GWM sample and GWM-FA-CR sample after 28 days of curing time.

For the GWM sample, the first endothermic peak, which begins at $110^{\circ} \mathrm{C}$, corresponds with the removal of hygroscopic water between the clay particles [57].

The mass loss between 500 and $560{ }^{\circ} \mathrm{C}$ is attributed to the dehydration of the clay minerals [58,59]. For GWM-FA-CR, we can observe that the clay's dehydration peaks are very low compared to those of the GWM sample. This phenomenon is due to the reactivity of these clay minerals with FA and CR to form CSH and CASH hydrated products. The 
mass loss at $295^{\circ} \mathrm{C}$ is attributed to the decomposition of hydroxides, such as goethite [60]. A discrete endothermic peak around $575^{\circ} \mathrm{C}$ can also be observed. This peak is attributed to the allotropic transformation of $\alpha$ into $\beta$-quartz [61].

The endothermic peaks at $720^{\circ} \mathrm{C}$, with a large range in the DSC curve, are due to the decomposition of calcium carbonates [62]. It is important to note that these endothermic peaks are strongly asymmetric, which indicates that the decomposition kinetic increases with temperature until the depletion of carbonates. The carbonate decomposition leads to $\mathrm{CO}_{2}$ release to the atmosphere.

The exothermic DTA peaks above $800{ }^{\circ} \mathrm{C}$, present only in the GWM sample, are associated with the decomposition of clay minerals. They form a new mineral with a spinel-type structure [63].

\subsubsection{Raman Spectroscopy Analyses}

The Raman analyses of the hydrated structures formed in the GWM-FA-CR after 28 days show the presence of tobermorite and Al-tobermorite (Figure 7). In addition to the CSH and CSAH phases, the Raman spectra also show the presence of quartz as well as calcite $[64,65]$. It is important to note that no trace of aragonite was detected. This is probably due to the complete dissolution of this phase. Indeed, the solubility ( $\log _{\mathrm{sp}}$ ) of aragonite in water at $25{ }^{\circ} \mathrm{C}$ is $-8.336 \pm 0.020$, leading to the formation of $\mathrm{Ca}^{2+}$ and $\mathrm{CO}_{3}{ }^{2-}$ ions [66]. Therefore, the dissolved $\mathrm{Ca}^{2+}$ ions will participate in the hydration reactions and then in the formation of the CSH and CASH phases.
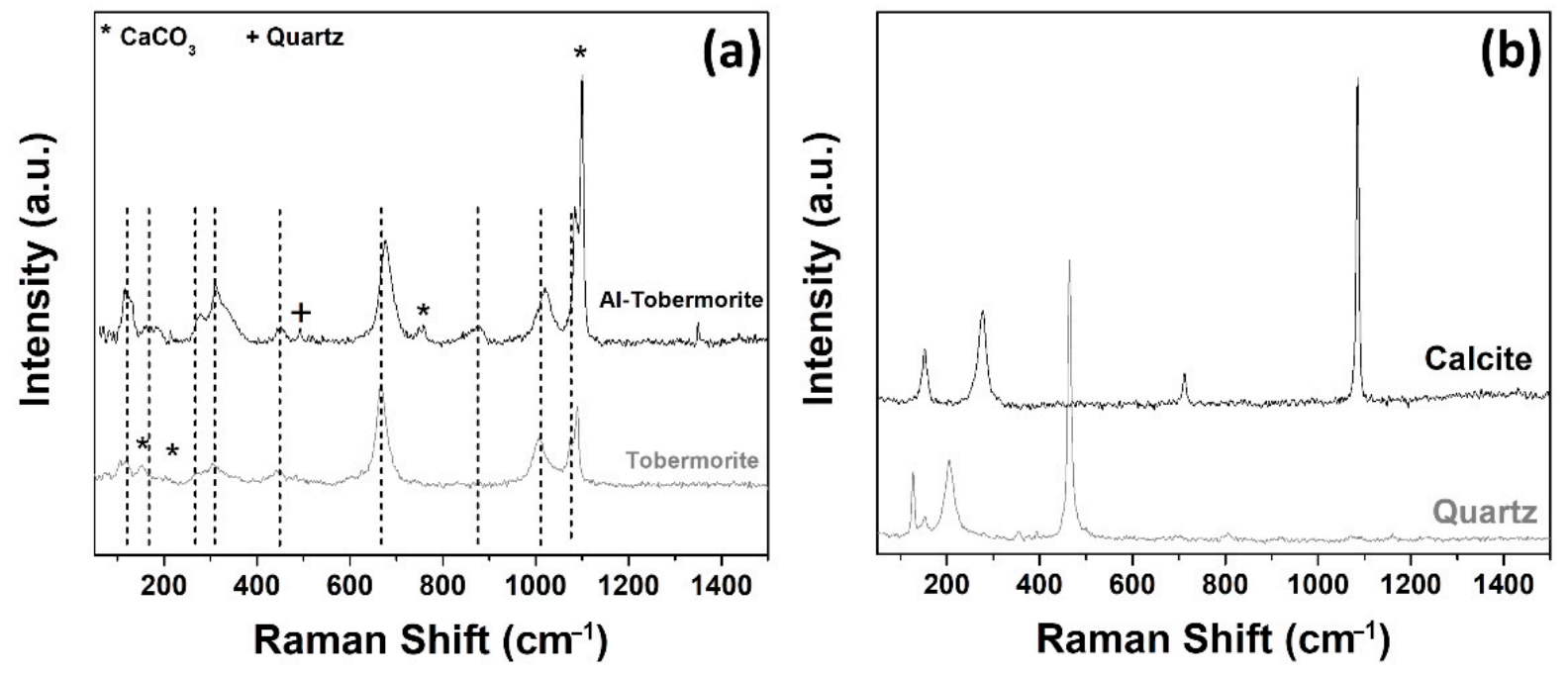

Figure 7. Raman spectra of the phases detected in the GMW-FA-CR mixture after 28 days of curing: (a) CSH and CASH, (b) calcite and quartz.

The nature of the hydrated CSH and CSAH structures have been largely studied by Raman spectroscopy $[67,68]$. All Raman spectra of tobermorite show the presence of the most intense vibration mode attributed to the Si-O stretching vibration at $665 \mathrm{~cm}^{-1}$ (Figure 7a). The band near $440 \mathrm{~cm}^{-1}$ is attributed to the $\mathrm{Si}-\mathrm{O}-\mathrm{Si}$ twisting and stretching modes. The vibration modes attributed to the lattice vibrations of $\mathrm{Ca}-\mathrm{O}$ polyhedra are present at low-wavenumber zones $\left(<350 \mathrm{~cm}^{-1}\right)$. The vibration modes in the wavenumber region between 850 and $1100 \mathrm{~cm}^{-1}$ are assigned to the $Q_{n}$ symmetric stretching modes of silicate Si-O.

The Raman spectra show that the $\mathrm{Q}_{2}$ symmetric stretching mode present at $1005-1020 \mathrm{~cm}^{-1}$ in the GWM-FA-CR specimen split into two vibration bands at 1007 and $1016 \mathrm{~cm}^{-1}$. This splitting is the signature of the $\mathrm{Si}-\mathrm{O}-\mathrm{Si}$ chain length modification by a change in the amount of silica tetrahedron $\mathrm{Q}_{2 p}$ (pairing) and $\mathrm{Q}_{2 \mathrm{~b}}$ (bridging) [69]. The split of $\mathrm{Q}_{2}$ is mainly due to a high quantity of fly ash silicon. Indeed, the silicates, brought by FA, react with the calcium originating from CR and GWM to form additional CSH gel as a result of a pozzolanic reaction, 
and thus lead to a reduction in porosity and enhanced strength. The Raman spectra show also the presence of the $\mathrm{C}-\mathrm{O}$ stretching mode in the $\mathrm{CaCO}_{3}$ group at $1085 \mathrm{~cm}^{-1}$.

For Al-tobermorite, we can observe that the wavenumbers of the vibration modes are red-shifted compared to those of pure tobermorite. This phenomenon is due to $\mathrm{Al}$ substitution in tobermorite. Al substitution in tobermorite induces a decrease in the cell parameters compared to those of tobermorite (Table 8). The Al substitution leads to an increase in the (002) interplanar crystal spacing due to the larger radius of $\mathrm{Al}^{3+}$ compared to $\mathrm{Si}^{4+}$ [70]. The substitution of $\mathrm{Al}$ enhanced the degree of the silicate chain polymerization in tobermorite [70].

The main hydration products responsible for the increase in mechanical performance properties are: tobermorite and alumino-silicate hydrates (Al-tobermorite).

\subsubsection{Thermal Conductivity of GMW-FA-CR}

A thermal conductivity $(\lambda)$ lowered to two-third the one of the standard cob is also observed for GMW-FA-CR (Table 9), with $0.58 \mathrm{~W} \cdot \mathrm{m}^{-1} \cdot \mathrm{K}^{-1}$ and $0.35 \mathrm{~W} \cdot \mathrm{m}^{-1} \cdot \mathrm{K}^{-1}$, respectively. This shows that the FA-CR addition improves the thermal insulation character of the GMW construction material.

Table 9. Thermal Conductivity of GWM-FA-CR Specimen and the Standard Cob Compared to Those of Cob Building Materials from the Literature.

\begin{tabular}{|c|c|c|}
\hline Sample & Density $\left(\mathrm{kg} \cdot \mathrm{m}^{-3}\right)$ & $\begin{array}{l}\text { Thermal Conductivity } \\
\left(\mathrm{W} \cdot \mathrm{m}^{-1} \cdot \mathrm{K}^{-1}\right)\end{array}$ \\
\hline GMW-FA-CR & $1910 \pm 5$ & $0.35 \pm 0.03$ \\
\hline Standard cob & $1843 \pm 5$ & $0.58 \pm 0.02$ \\
\hline $\begin{array}{l}\text { Cob materials from the } \\
\text { literature }[33,36,70-72]\end{array}$ & 1200-2000 & $0.47-0.93$ \\
\hline
\end{tabular}

This behavior is peculiar because the density of the standard cob is smaller than the one of GMW-FA-CR. In this latter, the greater density results in a smaller thermal conductivity, a sign of significant modifications of the thermal carriers in the material with the introduction of FA and CR. Our measurements cannot dissociate between the contribution of electrons and phonons to thermal conductivity, but the former contribution is generally more affected by density than the latter. In such low-electronic-conduction materials, the former can be expected to mainly contribute.

\subsubsection{Moisture Sorption Isotherm of GMW-FA-CR}

The curve shapes are similar for GMW-FA-CR and the cob specimens, and correspond to a sigmoid (Figure 8). The moisture sorption curves belong to type II isotherms [73]. An increase in the mass difference from the GWM-FA-CR to the cob specimen is noticed. This increase could be attributed to two main factors: porosity and differences in phase fractions (quantity of clay minerals) in the cob and the GMW-FA-CR specimen [74]. In the GWM-FA-CR, the addition of FA and aragonite originating from CR on the GWM lead to a decrease in clayey minerals. In addition, the porosity of the GWM-FA-CR mix is only two-third that of the standard cob (Table 10), further decreasing the mass difference.

\subsubsection{Specific Heat Capacity of GWM-FA-CR}

The specific heat capacity values for the GWM-FA-CR mix are between 925 and $1250 \mathrm{~J} \cdot \mathrm{kg}^{-1} \cdot \mathrm{K}^{-1}$. These values are very high compared to those of the standard cob specimen at all temperatures. (Figure 9). For the construction sector, building with materials with a high specific heat capacity performance is very important in regard to the energy aspect. In addition, the specific thermal capacity of materials is very important in the construction industry for the evaluation of the indoor comfort of the building's occupants. In summer, walls with a high thermal capacity keep rooms cool for a long time. In winter, they retain heat in buildings longer. 


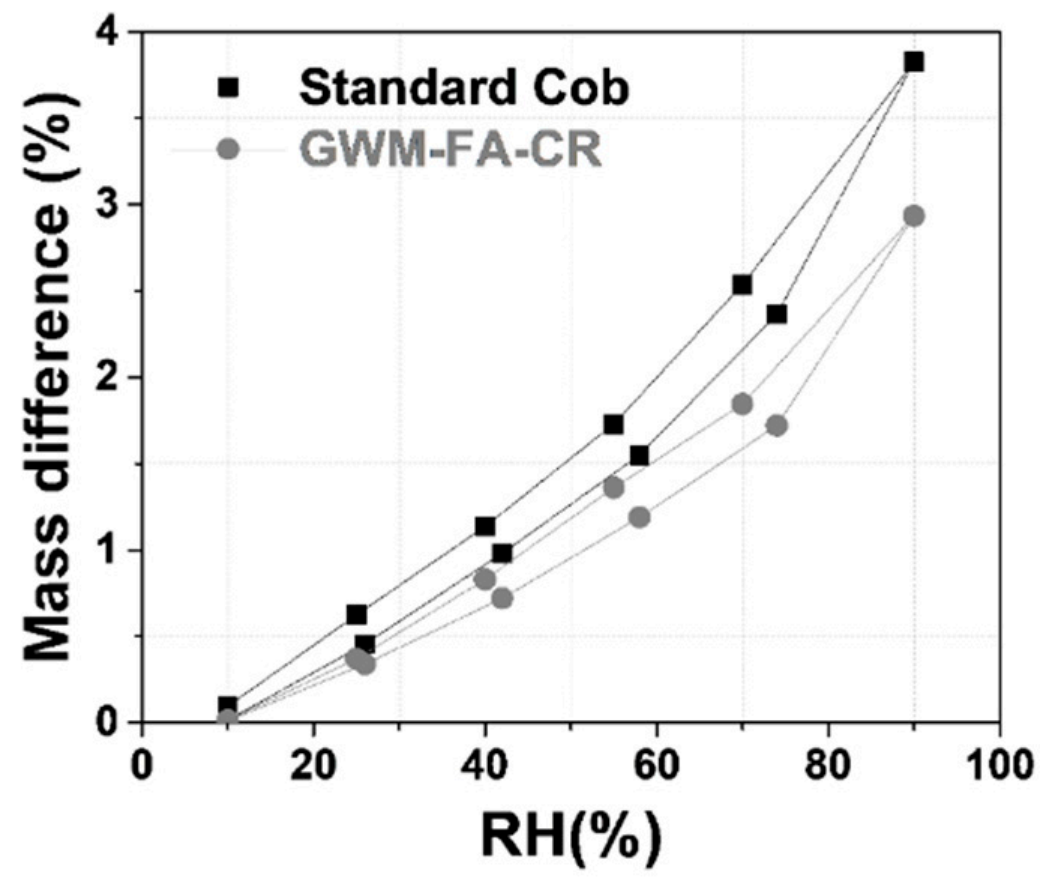

Figure 8. Moisture sorption isotherm of the GWM-FA-CR mix and a cob material at room temperature.

Table 10. Porosity Measured on the Cob Material and GWM-FA-CR Mix.

\begin{tabular}{ccc}
\hline Sample & Standard Cob & GMW-FA-CR \\
\hline Porosity & $61 \%$ & $42 \%$ \\
\hline
\end{tabular}

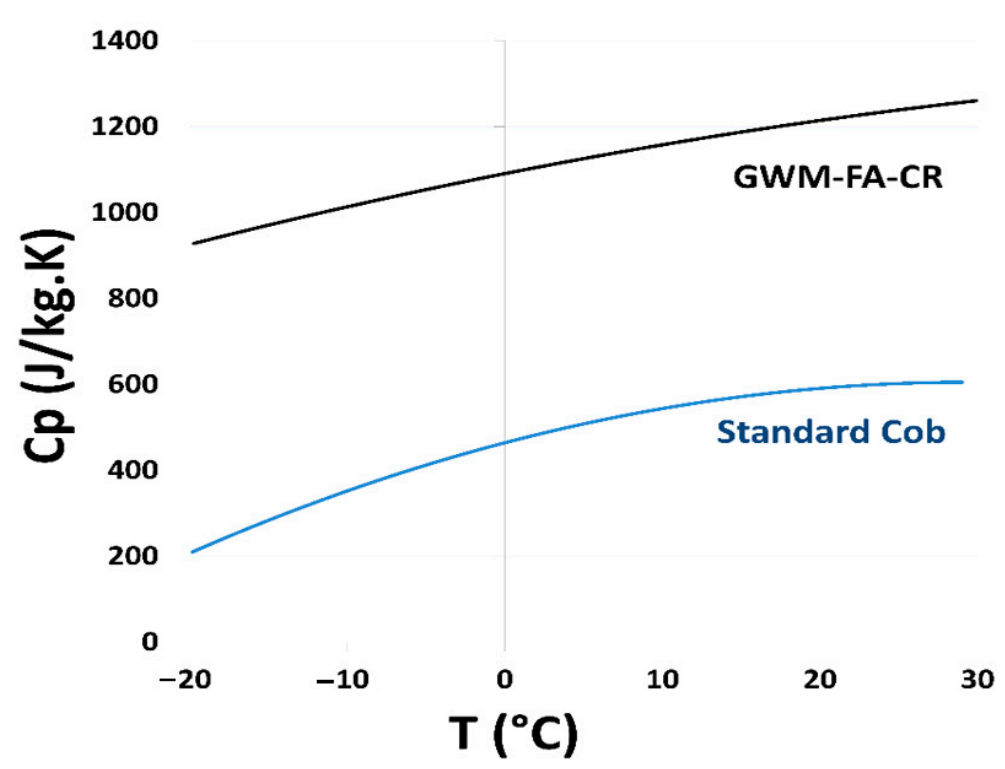

Figure 9. The variation in the specific heat capacity of the GWM-FA-CR mix and a standard cob material between $-20^{\circ} \mathrm{C}$ and $30^{\circ} \mathrm{C}$.

\subsubsection{Thermal Insulating Wall with GWM-FA-CR}

There is a strong tradition for cob constructions in Germany [75]. This system of construction is made with a secondary layer. The first layer is composed of traditional cob as a structural wall and the second layer, based on light earth, is used as a thermal insulating wall (Figure 10). 

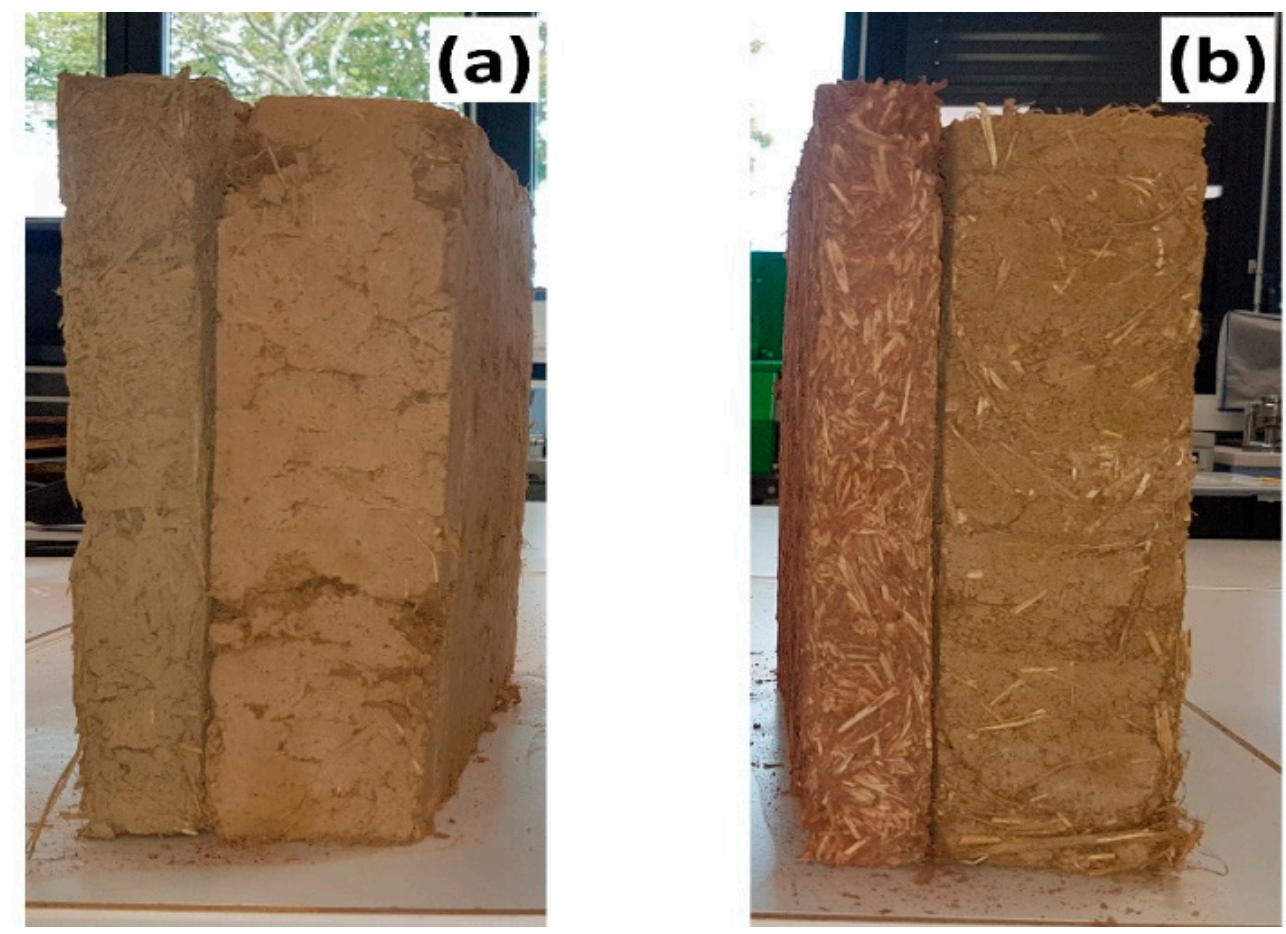

Figure 10. Cob walls with two layers: (a) GWM-FA-CR mixture and (b) usual cob.

For this purpose, we investigated the performance of the thermal and mechanical performance of a thermal insulating material based on a GWM-FA-CR mixture incorporating reed fibers (length between 4 and $6 \mathrm{~cm}$ ). According to the usual method in bibliography [33], the reed content used was $25 \%$.

The thermal conductivity of the light-earth wall based on GWM-FA-CR is $0.112 \mathrm{~W} \cdot \mathrm{m}^{-1} \cdot \mathrm{K}^{-1}$ at $20{ }^{\circ} \mathrm{C}$ (Table 11 ). For the standard cob insulating specimens, $\lambda$ is $0.157 \mathrm{~W} \cdot \mathrm{m}^{-1} \cdot \mathrm{K}^{-1}$ at $20^{\circ} \mathrm{C}$. This showed that the use of GWM-FA-CR lead to a decrease in thermal conductivity compared to light-earth material. In addition, we show that this GWM-FA-CR mixture enhanced the compressive strength of the earth insulating materials. This result is surprising and shows that we can use this GWM-FA-CR mixture for both structural and insulating walls. In terms of performance criteria, the suitability of GWM for earth construction without further additives was not possible due to the presence of swelling clay.

Table 11. Physical Properties of the Thermal Insulating Materials Based on GWM-FA-CR and 25\% Reed Fiber after 28 Days of Curing Compared to Those of Standard Cob Insulating Building Materials from the Literature.

\begin{tabular}{|c|c|c|}
\hline Sample & Compressive Strength (MPa) & Thermal Conductivity $\left(\mathrm{W} \cdot \mathrm{m}^{-1} \cdot \mathrm{K}^{-1}\right)$ \\
\hline GMW-FA-CR + 25\% reed fiber & $0.140 \pm 0.01$ & $0.112 \pm 0.005$ \\
\hline Standard cob insulating wall [26] & $0.079 \pm 0.01$ & $0.157 \pm 0.005$ \\
\hline
\end{tabular}

It is important to note that different GWM powders from 12 various quarries in Normandy have been studied by EDS, XRF and X-ray, and the quantitative analysis shows that the crystalline phases identified were quartz, calcite and muscovite, kaolinite and illite as clay minerals followed by iron oxy-hydroxides (Table 12). However, a rapid strength was observed and the maximal compressive strength achieved after 3 weeks of drying was around $5 \mathrm{MPa}$ for all the specimens made with GMW, 25\% of FA and 5\% of CR. Furthermore, with this addition, the content of swelling clays is reduced whatever the origin of GWM. 
Table 12. Chemical and Mineralogical Properties of Different GWM Specimens.

\begin{tabular}{cc}
\hline Chemical Analyses (in Weight. $\%$ ) & Mineralogy \\
\hline $\mathrm{SiO}_{2}$ : from 41 to $78 \%$ & Quartz: from 10 to $25 \%$ \\
$\mathrm{Al}_{2} \mathrm{O}_{3}$ : from 6 to $15 \%$ & Kaolinite: from 8 to $20 \%$ \\
$\mathrm{Fe}_{2} \mathrm{O}_{3}:$ from 5 to $12.5 \%$ & Calcite: from 23 to $35 \%$ \\
$\mathrm{CaO}:$ from 3 to $16 \%$ & Illite: from 11 to $19 \%$ \\
$\mathrm{MgO}$ : from 0.6 to $3.6 \%$ & Smectites: from 10 to $28 \%$ \\
$\mathrm{Na}_{2} \mathrm{O}<0.2 \%$ & Feldspaths: from 0 to $5 \%$ \\
$\mathrm{~K}_{2} \mathrm{O}:$ from 1 to $2.1 \%$ & Plagioclases: from 0 to $1 \%$ \\
$\mathrm{SO}_{3}<0.1$ & Iron oxy-hydroxides: from 1 to $6 \%$ \\
$\mathrm{P}_{2} \mathrm{O}_{5}<0.1$ & Micas: from 2 to $9 \%$ \\
$\mathrm{Cl}^{-}<0.2 \%$ & Swelling clays: from $\mathbf{9}$ to $18 \%$ \\
\hline
\end{tabular}

\section{Conclusions}

This study presents the effect of the use of a GMW-FNS-CR mix as an earth construction material. The thermal and mechanical characterizations of the GWM-FA-CR sample as well as the microstructural properties yield some encouraging results, which are highlighted as follows:

1. The use of GWM, CR and FA can greatly contribute to the Sustainable Development Goals (SDGs) and to reducing carbon emissions.

2. The formation of tobermorite and Al-tobermorite leads to high mechanical performance properties of the GWM specimen.

3. The increase in compressive strength compared to usual cob materials results in a reduction in the cob wall thickness, and therefore a gain in the quantities of materials used in cob construction.

4. The use of FA and CR provides two advantages:

(1) The high silica and calcium contents originating from FA and CR, respectively, react with clays and lead to the formation of tobermorite and Al-tobermorite as a result of a pozzolanic reaction, and thus lead to a reduction in porosity and enhanced strength.

(2) The thermal conductivity of the GMW-FA-CR is reduced and the specific heat capacity is enhanced compared to those of the usual cob construction materials used in Normandy.

Author Contributions: Conceptualization, Y.E.M.; methodology, Y.E.M. and M.B.; software, Y.E.M., D.C., S.G. and J.-F.B.; validation, Y.E.M., M.B., M.-H.B., F.K., M.L.G., D.C., S.G. and J.-F.B.; formal analysis Y.E.M., M.B., D.C. and J.-F.B.; investigation, Y.E.M., M.B. and M.-H.B.; data curation, Y.E.M.; writing-original draft preparation, Y.E.M., M.B., M.-H.B., D.C. and J.-F.B.; writing-review and editing, Y.E.M., M.B., M.-H.B., M.L.G., D.C., S.G. and J.-F.B.; visualization, Y.E.M. All authors have read and agreed to the published version of the manuscript.

Funding: This research is supported by the European Regional Development Fund for having sponsored this study in the frame of a BLUEPRINT to a Circular Economy project (Interreg V A France (Channel) England, Project $\mathrm{n}^{\circ} 206$ ).

Institutional Review Board Statement: Not applicable.

Informed Consent Statement: Not applicable.

Data Availability Statement: The data presented in the present paper are available from the corresponding author upon a reasonable request.

Acknowledgments: We thank LafargeHolcim for providing the gravel wash mud. This research is associated with the national DD\&RS strategy (Sustainable Development and Social Responsibility, 'développement durable et responsabilité sociale' in French).

Conflicts of Interest: The authors declare no conflict of interest. 


\section{References}

1. Jaquin, P. History of Earth Building Techniques. In Modern Earth Buildings, Materials, Engineering, Constructions and Applications; Woodhead Publishing Series in Energy; Woodhead Pub Ltd.: Oxford, UK, 2012; pp. 307-323.

2. Houben, H.; Guillaud, H. Earth Construction; Intermediate Technology Publications: London, UK, 1989.

3. Oti, J.E.; Kinuthia, J.M.; Bai, J. Engineering properties of unfired clay masonry bricks. Eng. Geol. 2009, 107, 130-139. [CrossRef]

4. Daoudi, L.; Rocha, F.; Costa, C.; Arrebei, N.; Fagel, N. Characterization of rammed-earth materials from the XVIth century Badii Palace in Marrakech, Morocco to ensure authentic and reliable restoration. Gearchaeology 2018, 33, 529-541. [CrossRef]

5. Schroeder, H. Sustainable Building with Earth; Springer International Publishing: Cham, Switzerland, 2016; pp. 1-576.

6. Allinson, D.; Hall, M. Hygrothermal analysis of a stabilised rammed earth test building in the UK. Energy Build. 2010, 42, 845-852. [CrossRef]

7. Adeguna, O.B.; Adedeji, Y.M.D. Review of economic and environmental benefits of earthen materials for housing in Africa. Front Archit. Res. 2017, 6, 519-528. [CrossRef]

8. Abanda, F.; Nkeng, G.; Tah, J.; Ohandja, E.; Manjia, M. Embodied energy and $\mathrm{CO}_{2}$ analyses of mud-brick and cement- block houses. AIMS Energy 2014, 2, 18-40.

9. Alausa, S.; Adekoya, B.; Aderibigbe, J.; Nwaokocha, C. Thermal characteristics of laterite-mud and concrete-block for walls in building construction in Nigeria. Int. J. Eng. Appl. Sci. 2013, 4, 8269.

10. Sharma, V.; Marwaha, B.M.; Vinayak, H.K. Enhancing durability of adobe by natural reinforcement for propagating sustainable mud housing. Int. J. Sustain. Built Environ. 2016, 5, 141-155. [CrossRef]

11. Thapa, V.B.; Waldmann, D.; Wagner, J.-F.; Lecomte, A. Assessment of the suitability of gravel wash mud as raw material for the synthesis of an alkali-activated binder. Appl. Clay Sci. 2018, 161, 110-118. [CrossRef]

12. Thapa, V.B.; Waldmann, D.; Simon, C. Gravel wash mud, a quarry waste material as supplementary cementitious material (SCM). Cem. Concr. Res. 2019, 124, 105833. [CrossRef]

13. UNPG, 2019. Translated from French (L'industrie Française des Granulats. Edition 2019—French Aggregates Industry. 2019). Available online: http://www.unpg.fr/wp-content/uploads/stat-unpg-chiffres-2017-web.pdf (accessed on 25 September 2021).

14. Rakhimova, N.R.; Rakhimov, R.Z. Literature Review of Advances in Materials Used in Development of Alkali-Activated Mortars, Concretes, and Composites. J. Mater. Civil. Eng. 2019, 31, 03119002. [CrossRef]

15. Zami, M.S.; Lee, A. Contemporary Earth Construction in Urban Housing-Stabilised or Unstabilised? School of the Built Environment, University of Salford: Salford, UK, 2008.

16. Brady, N.C.; Weil, R.R. The Nature and Properties of Soils, 13th ed.; Pearson Education Inc.: Upper Saddle River, NJ, USA, 2002; p. 621.

17. Gu, S.; Kang, X.; Wang, L.; Lichtfouse, E.; Wang, C. Clay mineral adsorbents for heavy metal removal from wastewater: A review. Environ. Chem. Lett. 2019, 17, 629-654. [CrossRef]

18. Gallipoli, D.; Bruno, A.W.; Perlot, C.; Mendes, J. A geotechnical perspective of raw earth building. Acta. Geotechnica. 2017, 12, 463-478. [CrossRef]

19. Rose, C.M.; Stegemann, J.A. From Waste Management to Component Management in the Construction Industry. Sustainability 2018, 10, 229. [CrossRef]

20. Villamizara, M.C.N.; Araquea, V.S.; Reyesa, C.A.R.; Silva, R.S. Effect of the addition of coal-ash and cassava peels on the engineering properties of compressed earth blocks. Constr. Build. Mater. 2012, 36, 276-286. [CrossRef]

21. Limaa, S.A.; Varumb, H.; Salesa, A.; Netoc, V.F. Analysis of the mechanical properties of compressed earth block masonry usingthe sugarcane bagasse ash. Constr. Build. Mater. 2012, 35, 829-837. [CrossRef]

22. Thomas, J.I.; Namitha, J.J.; Mathew, R.; Reji, R. Mud Bricks Using Oyster Shells. In National Conference on Structural Engineering and Construction Management SECON 2019: Proceedings of SECON'19, Angamaly, India, 15-16 May 2019; Springer Nature Switzerland AG: Cham, Switzerland, 2019; pp. 205-211.

23. Cabrera, J.; Rojas, M.F. Mechanism of hydration of the metakaolin-lime-water system. Cement. Concr. Res. 2001, 31, 177-182. [CrossRef]

24. Gameiro, A.L.; Silva, A.S.; Veiga, R.D.M.; Velosa, A. Lime-metakaolin hydration products: A microscopy analysis. Mater. Technol. 2012, 46, 145-148.

25. Gameiro, A.L.; Silva, A.S.; Veiga, R.D.M.; Velosa, A. Hydration products of lime-metakaolin pastes at ambient temperature with ageing. Thermochim. Acta. 2012, 535, 36-41. [CrossRef]

26. Bouasria, M.; El Mendili, Y.; Benzaama, M.H.; Pralong, V.; Bardeau, J.F.; Hennequart, F. Valorisation of stranded Laminaria digitata seaweed as an insulating earth material. Constr. Build. Mater. 2021, 308, 125068. [CrossRef]

27. Vichan, S.; Rachan, R.; Horpibulsuk, S. Strength and microstructure developmentin Bangkok clay stabilized with calcium carbide residue and biomass ash. Sci. Asia. 2013, 39, 186-193. [CrossRef]

28. Horpibulsuk, S.; Phetchuay, C.; Chinkulkijniwat, A. Soil stabilization by calciumcarbide residue and fly ash. J. Mater. Civil Eng. 2012, 24, 184-194. [CrossRef]

29. Siddiqua, S.; Barreto, P.N.M. Chemical stabilization of rammed earth using calcium carbide residue and fly ash. Constr. Build. Mater. 2018, 169, 364-371. [CrossRef]

30. Zierold, K.M.; Sears, C.G.; Hagemeyer, A.N. Protocol for measuring indoor exposure to coal fly ash and heavy metals. and neurobehavioural symptoms in children aged 6 to 14 years old. BMJ Open 2020, 10, e038960. [CrossRef] 
31. Kampala, A.; Horpibulsuk, S.; Prongmanee, N.; Chinkulkijniwat, A. Influence ofwet-dry cycles on compressive strength of calcium Carbide residue-fly ash stabilized clay. J. Mater. Civil Eng. 2014, 26, 633-643. [CrossRef]

32. Lekshmi, M.S.; Vishnudas, S.; Nair, D.G. An investigation on the potential of mud as sustainable building material in the context of Kerala. Int. J. Energy Technol. Policy 2017, 13, 107-122. [CrossRef]

33. Goodhew, S.; Boutouil, M.; Streiff, F.; Le Guern, M.; Carfrae, J.; Fox, M. Improving the thermal performance of earthen walls to satisfy current building regulations. Energy Build. 2021, 240, 110873. [CrossRef]

34. Bouasria, M.; Khadraoui, F.; Benzaama, M.H.; Chateigner, D.; Gascoin, S.; Pralong, V.; Orberger, B.; Babouri, L.; El Mendili, Y. Partial substitution of cement by the association of Ferronickel slags and Crepidula fornicata shells. J. Build. Eng. 2021, $33,101587$. [CrossRef]

35. Yalcin, S.; Chateigner, D.; Le Pluart, L.; Gascoin, S.; Eve, S. Investigation of structural and mechanical properties of BioCaCO ${ }_{3}$ LDPE composites. Mat. Int. 2019, 1, 29-43. [CrossRef]

36. Phung, T.A.; Le Guern, M.; Boutouil, M.; Louahlia, H. Hygrothermal Behaviour of Cob Material. In Proceedings of the International Symposium on Earthen Structures 2018, IISc, Bangalore, India, 22-24 August 2018.

37. El Mendili, Y.; Vaitkus, A.; Merkys, A.; Gražulis, S.; Chateigner, D.; Mathevet, F.; Gascoin, S.; Petit, S.; Bardeau, J.-F.; Zanatta, M.; et al. Raman Open Database: First interconnected Raman-X-ray diffraction open-access resource for material identification. J. Appl. Cryst. 2019, 52, 618-625. [CrossRef] [PubMed]

38. Caglioti, G.; Paoletti, A.; Ricci, F.P. Choice of collimators for a crystal spectrometer for neutron diffraction. Nucl. Instrum. 1958, 3 , 223-228. [CrossRef]

39. Grazulis, S.; Daškevič, A.; Merkys, A.; Chateigner, D.; Lutterotti, L.; Quirós, M.; Serebryanaya, N.R.; Moeck, P.; Downs, R.T.; Le Bail, A. Crystallography Open Database (COD): An open-access collection of crystal structures and platform for world-wide collaboration. Nucleic. Acids. Res. 2012, 40, D420-D427. [CrossRef]

40. Lutterotti, L.; Matthies, S.; Wenk, H.R.; Schultz, A.S.; Richardson, J.W. Combined texture and structure analysis of deformed limestone from time-of-flight neutron diffraction spectra. J. Appl. Phy. 1997, 81, 594-600. [CrossRef]

41. AFNOR. NF EN ISO 12572_Performance Hygrothermique des Matériaux et Produits pour le Bâtiment-Détermination des Propriétés de Transmission de la Vapeur d'eau; NF EN ISO 12572; AFNOR: Paris, France, 2001.

42. Plastiques-Analyse calorimétrique différentielle (DSC)—Partie 4: Détermination de la capacité thermique massique, NF EN ISO 11357-4. 2014. Available online: https:/ / sagaweb.afnor.org/ (accessed on 25 September 2021).

43. Brunauer, S.; Emmett, P.H.; Teller, E. Adsorption of gases in multimolecular layers. J. Am. Chem. Soc. 1938, 60, 309-319. [CrossRef]

44. Barton, C.D.; Karathanasis, A.D. Clay Minerals. In Encyclopedia of Soil Science; Lal, R., Ed.; Marcel Dekker: New York, NY, USA, 2002; pp. 187-192.

45. Mookherjee, M.; Mainprice, D.; Maheshwari, K.; Heinonen, O.; Patel, D.; Hariharan, A. Pressure induced elastic softening in framework aluminosilicate-albite (NaAlSi3O8). Sci. Rep. 2016, 6, 34815. [CrossRef]

46. Andrade, F.A.; Al-Qureshi, H.A.; Hotza, D. Measuring the plasticity of clays: A review. Appl. Clay Sci. 2011, 51, 1-7. [CrossRef]

47. Biagioni, C.; Merlino, S.; Bonaccorsi, E. The tobermorite supergroup: A new nomenclature. Mineral. Mag. 2015, 79, 485-495. [CrossRef]

48. Komarneni, S.; Roy, D.M.; Roy, R. Al-substituted tobermorite -shows cation exchange. Cem. Concr. Res. 1982, 6, 773-780. [CrossRef]

49. Faucon, P.; Petit, J.C.; Charpentier, T.; Jacquinot, J.F.; Adenot, F. Silicon Substitution for Aluminum in Calcium Silicate Hydrates. J. Am. Ceram. Soc. 1999, 82, 1307-1312. [CrossRef]

50. Komarneni, S.; Roy, R.; Roy, D.M.; Fyfe, C.A.; Kennedy, G.J.; Bothner-By, A.A.; Dadok, J.; Chesnick, A.S. ${ }^{27} \mathrm{Al}$ and29Si magic angle spinning nuclear magnetic resonance spectroscopy of Al-substituted tobermorites. J. Mater. Sci. 1985, 20, 4209-4214. [CrossRef]

51. Paradiso, P.; Santos, R.L.; Horta, R.B.; Lopes, J.N.C.; Ferreira, P.J.; Colaço, R. Formation of nanocrystalline tobermorite in calcium silicate binders with low C/S ratio. Acta Mater. 2018, 152, 7-15. [CrossRef]

52. Luo, F.; Wei, C.; Xue, B.; Wang, S.; Jiang, Y. Dynamic hydrothermal synthesis of Al-substituted 11 A tobermorite from solid waste fly ash residue-extracted $\mathrm{Al}_{2} \mathrm{O}_{3}$. Res. Chem. Intermed. 2013, 39, 693-705. [CrossRef]

53. Bernstein, S.; Fehr, K.T. The formation of $1.13 \mathrm{~nm}$ tobermorite under hydrothermal conditions: 1 . the influence of quartz grain size within the system $\mathrm{CaO}-\mathrm{SiO}_{2}-\mathrm{D}_{2} \mathrm{O}$. Prog. Cryst. Growth Charact. Mater. 2012, 58, 84-91. [CrossRef]

54. Michel, M.; Georgin, J.F.; Ambroise, J. Improving the mechanical performance of high-grade slag cement by the addition of Portland cement and sulfoaluminate cement. Constr. Build. Mater. 2012, 37, 291-300. [CrossRef]

55. Ismail, I.; Bernal, S.A.; Provis, J.L.; Hamdan, S.; van Deventer, J.S.J. Dryinginduced changes in the structure of alkali-activated pastes. J. Mater. Sci. 2013, 48, 3566-3577. [CrossRef]

56. Ma, B.; Liu, X.; Tan, H.; Zhang, T.; Mei, J.; Qi, H.; Jiang, W.; Zou, F. Utilization of pretreated fly ash to enhance the chloride binding capacity of cement-based material. Constr. Build. Mater. 2018, 175, 726-734. [CrossRef]

57. Alastair, M.; Andrew, H.; Pascaline, P.; Mark, E.; Pete, W. Alkali activation behaviour of un-calcined montmorillonite and illite clay minerals. Appl. Clay Sci. 2018, 166, 250-261.

58. Stolboushkin, A.Y.; Ivanov, A.I.; Syromyasov, V.A.; Fomina, O.A. A study on sintering of ceramic bricks made from waste coal. IOP Conf. Ser. Earth Environ. Sci. 2016, 45, 012018. [CrossRef]

59. Elkhalifah, A.E.I.; Maitra, S.; Bustam, M.A.; Murugesan, T. Thermogravimetric analysis of different molar mass ammonium cations intercalated different cationic forms of montmorillonite. J. Therm. Anal. Calorim. 2012, 110, 765-771. [CrossRef] 
60. Laskou, M.; Margomenou-Leonidopoulou, G.; Balek, V. Thermal characterization of bauxite samples. J. Therm. Anal. Calorim. 2006, 84, 141-146. [CrossRef]

61. Dollimore, D.; Tong, P.; Alexander, K.S. The kinetic interpretation of the decomposition of calcium carbonate by use of relationships other than the Arrhenius equation. Thermochim. Acta 1996, 13, 282-283. [CrossRef]

62. Barba, A.; Beltrán, V.; Feliu, C.; García, J.; Ginés, F.; Sánchez, E.; Sanz, V. Raw Materials for Fabrication of Supports to Clay Ceramics; AICE/ITC: Castellón, Spain, 1997.

63. Carty, W.; Senapati, U. Porcelain-raw materials, processing, phase evolution and mechanical strength. J. Am. Ceram. Soc. 1998, 81, 3-20. [CrossRef]

64. El Mendili, Y.; Chateigner, D.; Orberger, B.; Gascoin, S.; Bardeau, J.-F.; Petit, S.; Duée, C.; Le Guen, M.; Pilliere, H. Combined XRF, XRD, SEM-EDS and Raman analyses on serpentinized harzburgite (Nickel laterite mine, New Caledonia): Implications for exploration and geometallurgy. ACS Earth. Space. Chem. 2019, 3, 2237-2249. [CrossRef]

65. Ait Chaou, A.; Abdelouas, A.; El Mendili, Y.; Bouakkaz, R.; Utsunomiya, S.; Martin, C.; Bourbon, X. Vapor hydration of a simulated borosilicate nuclear waste glass in unsaturated conditions at $50{ }^{\circ} \mathrm{C}$ and $90{ }^{\circ} \mathrm{C}$. RSC Adv. 2015, 5, 64538-64549. [CrossRef]

66. Plummer, L.N.; Busenberg, E. The Solubilities of Calcite, Aragonite, and Vaterite in $\mathrm{CO}_{2}-\mathrm{H}_{2} \mathrm{O}$ Solutions between 0 and $90{ }^{\circ} \mathrm{C}$, and an Evaluation of the Aqueous Model for the System $\mathrm{CaCO}_{3}-\mathrm{CO}_{2}-\mathrm{H}_{2} \mathrm{O}$. Geochim. Cosmochim. Acta. 1982, 46, 1011-1040. [CrossRef]

67. Bouasria, M.; Babouri, L.; Khadraoui, F.; Chateigner, D.; Gascoin, S.; Pralong, V.; Benzaama, M.H.; Orberger, B.; El Mendili, Y. Insight into the partial replacement of cement by ferronickel slags from New Caledonia. Eur. J. Environ. Civ. Eng. 2020. [CrossRef]

68. Garbev, K.; Stemmermann, P.; Black, L.; Breen, C.; Yarwood, J.; Gasharova, B. Structural features of C-S-H(I) and its carbonation in air-A Raman spectroscopic study. Part I: Fresh phases. J. Am. Ceram. Soc. 2007, 90, 900-907. [CrossRef]

69. Grangeon, S.; Claret, F.; Roosz, C.; Sato, T.; Gaboreau, S.; Linard, Y. Structure of nanocrystalline calcium silicate hydrates: Insights from X-ray diffraction, synchrotron X-ray absorption and nuclear magnetic resonance. J. Appl. Crystallogr. 2016, 49, 771-783. [CrossRef]

70. Liao, W.; Li, W.; Fang, Z.; Lu, C.; Xu, Z. Effect of Different Aluminum Substitution Rates on the Structure of Tobermorite. Materials 2019, 12, 3765. [CrossRef]

71. Minke, G. Earth Construction Handbook; WIT Press: Boston, MA, USA, 2000.

72. Phung, T.-A.; Le Guern, M.; Boutouil, M.; Louahlia, H. Mechanical and thermal performance of cob materials. Acad. J. Civ. Eng. 2017, 35, 166-172. [CrossRef]

73. IUPAC: International Union of Pure and Applied Chemistry. Reporting physisorption data for gas/solid systems with special reference to the determination of surface area and porosity. Pure Appl. Chem. 1985, 57, 603-619. [CrossRef]

74. Van Oss, C.; Giese, R. The hydrophilicity and hydrophobicity of clay minerals. Clays. Clay. Miner. 1995, 43, 474-477. [CrossRef]

75. Volhard, F. Light Earth Building: A Handbook for Building with Wood and Earth; Birkhäuser: Basel, Switzerland, 2016. 